\title{
Die invloed van klimaatverandering op die Suid-Afrikaanse stad en voorgestelde aanpassings
}

\section{Dirk Conradie}

http://dx.doi.org/10.18820/2415-0495/trp68i1.3

Peer review and revised

\section{Opsomming}

Die doel van hierdie artikel is om die effek van klimaatverandering op die SuidAfrikaanse stad te ondersoek en toepaslike maatreëls aan die hand te doen, gebaseer op die spesifieke klimaatstreek. Met toenemende klimaatverandering word dit al hoe belangriker dat Suid-Afrikaanse stede veerkragtig (resilient) moet wees. Onlangs is nuwe klimaat- en energiekaarte by die WNNR geproduseer om die huidige SANS 204 (2011) Suid-Afrikaanse Nasionale Boustandaard ses sonekaart te vervang. Ten einde die langtermyn toepaslikheid van die kaart te verseker, is daar bo en behalwe die gebruik van historiese klimaatdata ook data oor klimaatverandering in berekening gebring om die kaart te skep. 'n A2 klimaatverandering van die Special Report on Emission Scenarios (SRES) vir die periode 1961-2100 (Engelbrecht, Landman, Engelbrecht, Landman, Bopape, Roux, McGregor \& Thatcher, 2011: 649) is gebruik. ' $\mathrm{n}$ A2 scenario kan beskryf word as besigheid soos gewoon. Volgens onlangse navorsing kan suidelike Afrika 'n temperatuurstyging van tussen $4^{\circ} \mathrm{C}$ tot $6^{\circ} \mathrm{C}$ verwag in die westelike warm woestyngebiede van suidelike Afrika (Engelbrecht \& Engelbrecht, 2016: 247-261). Terselfdertyd verhoog die hoeveelheid energie in die atmosfeer wat lei tot 'n verhoogde intensiteit van storms (Emanuel, 2005: 686-688). Die toenemende verwarming sal 'n groot impak op stede hê waar die sogenaamde Stedelike Hitte Eiland (SHE)-effek veroorsaak dat die stede heelwat warmer word as die omliggende landelike gebiede. Al bogenoemde faktore toon aan dat klimaatverandering 'n aansienlike impak op die Suid-Afrikaanse stad sal hê.

Sleutelwoorde: Klimaatverandering, stede, Suid-Afrika

\section{THE IMPACT OF CLIMATE CHANGE ON THE SOUTH AFRICAN CITY AND RECOMMENDED MITIGATING MEASURES}

The purpose of this article is to research the effect of climate change on the South African city and to recommend appropriate measures, based on the specific climatic zone. With increased climate change, it is getting increasingly important that the South African city should be resilient. Recently, the CSIR produced new climate and energy maps to replace the SANS 204 (2011) South African National Building Standards six zone climatic region map. To ensure the long-term applicability of the new climate map, it was decided that, over and above the use of historic climatic data, climate change should also be considered. An A2 climate change scenario of the Special Report on Emission Scenarios (SRES) for the period 1961-2100 (Engelbrecht et al., 2011: 649) was used. An A2 scenario can be described as business as usual. Recent research predicts that southern Africa can expect a temperature increase of between $4^{\circ} \mathrm{C}$ to $6^{\circ} \mathrm{C}$ in hot western dessert areas (Engelbrecht \& Engelbrecht, 2016: 247-261). Simultaneously, the amount of energy in the atmosphere increases, causing higher intensity storms (Emanuel, 2005: 686-688). The significant warming will have a severe impact on cities where the so-called Urban Heat Island (UHI) causes cities to be significantly warmer than surrounding rural areas. These factors indicate that climate change will have a significant impact on the southern African city.

Keywords: Climate change, cities, South Africa

\section{KGAHLAMELO YA PHETOHO MAEMONG A LEHODIMO MOTSETOROPONG WA AFRIKA BORWA LE MEKGWA YA PEBOFATSO E KGOTHALLEDITSWENG}

Sepheo sa atikele ena ke ho batlisisa dikgahlamelo tsa phetoho ya maemo a lehodimo motsetoropong wa Afrika Borwa le ho kgothalletsa mekgwa e tshwanelehileng ho ya ka maemo a kgethehileng a lehodimo. Ka baka la ho eketseha ha phetoho ya boemo ba lehodimo, ho ntse ho eba bohlokwa le ho feta hore motsetoropo wa Afrika Borwa o elwe hloko. Haufinyana, CSIR e entse di mmepe tse ntjha tsa maemo a lehodimo le tsa matla a motlakase ho tlosa mmapa wa SANS 202 (2011) South African National Building Standards six zone climate region. Ho etsa bonnete ba hore ho na le mmapa o motjha wa maemo a lehodimo o tshwanelehileng bakeng sa nako e telele, ho entswe qeto ya hore ka hodima tshebetso ya pokello ya dintlha tsa nalane; phetoho maemong a lehodimo le yona e tlameha ho elwa hloko. Ho sebedisitswe A2 ya thaloso ya diketsahalo tse tla etsahala tsa nako e tlang mabapi le phetoho ya maemo a lehodimo ya Special Report on Emission Senarios (SRES) nakong ya 1961 ho fihlela 2100 (Engelbrecht et al., 2011: 649). Tlhaloso ya A2 ya diketsahalo tse tla etsahala nakong e tlang e ka hlaloswa e le mosebetsi wa tlwaelo. Dipatlisiso tsa nakwana e fetileng di lepa hore Afrika e ka Borwa e ka lebella nyoloho ya themphereitjha pakeng tsa 4 ho ya ho $6{ }^{\circ} \mathrm{C}$ dibakeng tse chesang tsa lehwatata le ka Bophirima (Engelbrecht et al., 2016: 247-261). Nakong yona eo, palo ya matla sepakapakeng/sebakeng e a nyoloha, hona ho etsa hore hobe le difefo tse matla (Emanuel, 2005: 686-688). Mofuthu o matla o tla ba le kgahlamelo e mpe haholo bakeng sa metsetoropo moo Urban Heat Island (UHI) e etsang hore e be mofuthu haholo, ho feta dibaka tsa mapolasi tse e potapotileng. Dintlha tse boletsweng ka hodimo di bontsha hore ho tla ba le kgahlamelo e kgolo bakeng sa metsetoropo e Borwa ba Afrika ka baka la phetoho ya maemo a lehodimo.

Mantswe a sehlooho: Phetoho ya maemo a lehodimo, metsetoropo, Afrika Borwa

\section{INLEIDING}

Op 27 Oktober 2015 het die dorp Vredendal aan die weskus van Suid-Afrika 'n temperatuur van $48.4^{\circ} \mathrm{C}$ ondervind. Terselfdertyd het 
een van die sterkste orkane wat nog ooit aangeteken is, die weskus van Mexiko genader (Patricia).

Droogtes en temperature, aansienlik hoër as normaal, wat toegeskryf kan word aan 'n sterk ontwikkelde El Niño (bo-normale see-oppervlak temperatuur anomalie van $4^{\circ} \mathrm{C}$ in die Stille Oseaan) is gedurende hierdie tydperk ondervind. In Desember 2015 het Pretoria 'n ongekende hittegolf, wat 'n maksimum van $42.5^{\circ} \mathrm{C}$ bereik het, ondervind. Daar is geen twyfel dat klimaatverandering lei tot meer hittegolwe, 'n meer dikwelse voorkoms van swaar reënval, en droogtes (Engelbrecht, Adegoke, Bopape, Naidoo, Garland, Thatcher, McGregor, Katzfey, Werner, Ichoku \& Gatebe, 2015: 1-14; Garland, Matooane, Engelbrecht, Bopape, Landman, Naidoo, Van Der Merwe \& Wright, 2015: 12577-12604). Emanuel (2005) het waargeneem dat die hoeveelheid energie in die atmosfeer toeneem met 'n toename in globale gemiddelde temperature wat aanleiding gee tot hewiger storms. Die toename in temperatuur veroorsaak ook 'n meer intense
Stedelike Hitte-Eiland (SHE)-effek. Die SHE-effek word veroorsaak deur die absorpsie van sonlig deur harde oppervlaktes, die tekort aan verdamping en die uitstraling van hitte deur menslike aktiwiteite (antropogeniese hitte) (Figuur 3). Die SHE-effek is reeds in 1818 deur Luke Howard met sorgvuldige weerkundige waarneming in Londen ontdek (Mayor of London, 2006: 2). As stede nie hiervoor voorbereid is nie, sal dit die inwoners se gesondheid (mortaliteit), lewenskwaliteit, produktiwiteit en gerief in huise en geboue nadelig beïnvloed wat uiteindelik tot ekonomiese probleme sal lei. Die aanpassing vir klimaatverandering is die gekombineerde effek van lokale maatreëls binne die plaaslike konteks. Die gebruik van generiese maatreëls vir ' $n$ hele stad is minder effektief. In die algemeen kan 'n wye verskeidenheid van maatreëls op verskillende vlakke getref word. Daar is die versameling en opberg van reënwater, koeler ontwerp van strate en oop ruimtes, en toepaslike aanpassings in gebou-ontwerp.
Menslike gedrag kan verander word soos die voorkoming van nadelige effekte wanneer buitengewone klimaatsgebeure plaasvind asook die versorging van bejaardes in uitermate warm of koue weerstoestande (Van Hove, Blocken, Van den Dobbelsteen, Spit \& Bosch, 2014: 3-4).

Dertien van die 30 Köppen-Geiger klimaatstreke kom in Suid-Afrika voor (Conradie, Van Reenen, \& Bole, 2015: 83-91). Suid-Afrika het 'n geweldige variasie in topografie, reënval, humiditeit en plantegroei, wat dit duidelik maak dat daar nie 'n enkele stel maatreëls bestaan wat toegepas kan word nie. Dit is in teenstelling met Nederland met slegs een, die Britse Eilande met twee en die Verenigde State met 16 klimaatstreke. Hierdie geweldige variasie in klimaat beteken dat die verskillende stede reeds op die oomblik verskillende maatreëls behoort te tref vir stadsbeplanning en gebou-ontwerp. Dieselfde stede sal toenemend aanpasbaar moet wees om die

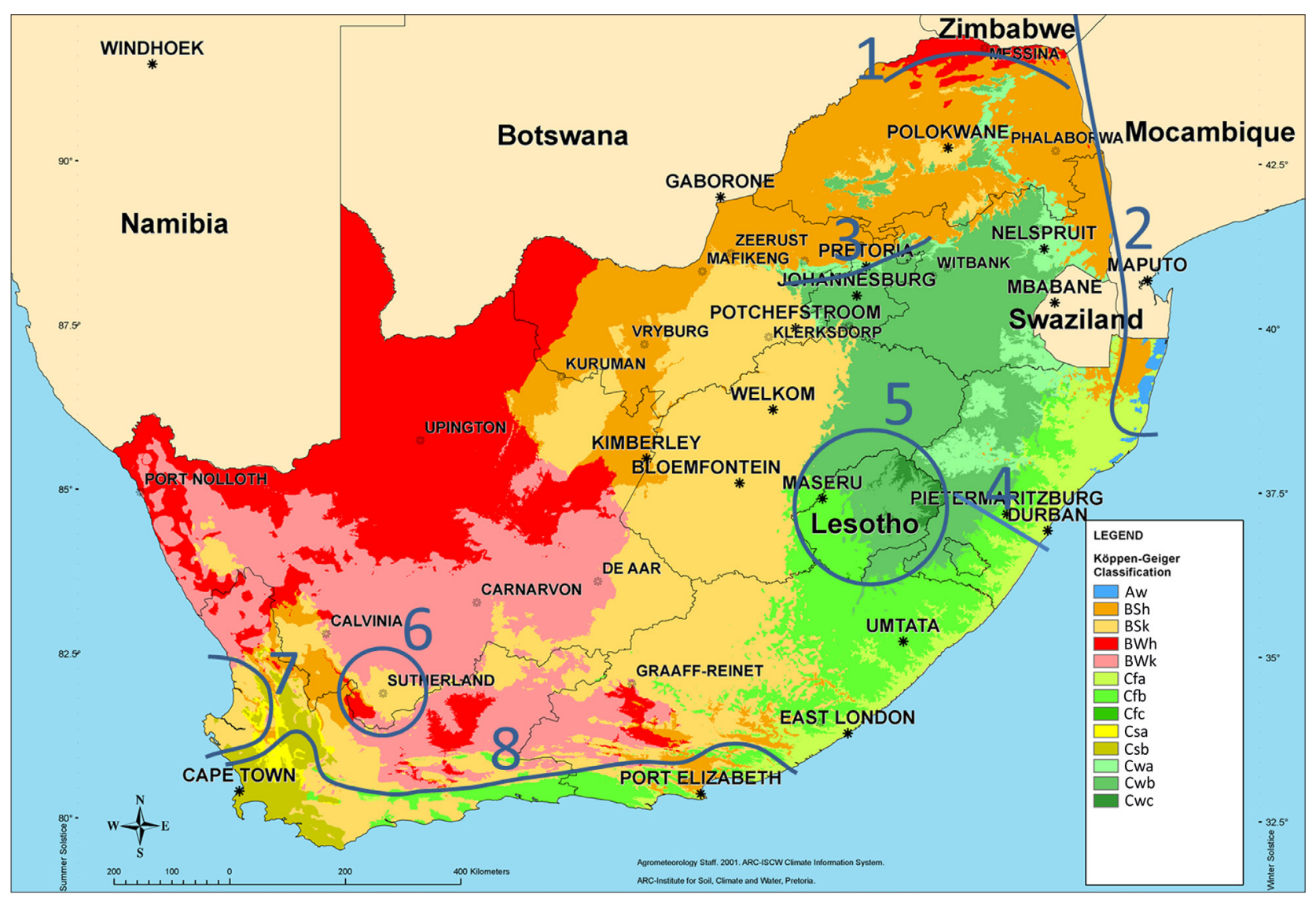

Figuur 1: WNNR Köppen-Geiger klimaatkaart gebaseer op 1985 tot 2005 Landbou Navorsingsraad data op 'n baie fyn $1 \mathrm{~km} \times 1 \mathrm{~km}$ ruitnet

Bron: $\quad$ Gebaseer op Conradie, Van Reenen \& Bole, 2015: 83-91 
invloede van klimaatverandering suksesvol te hanteer veral omdat klimaatverandering verskillende klimaatstreke progressief verskillend beïnvloed.

\section{KÖPPEN-GEIGER KLIMAATKAARTE}

Die Köppen-Geiger

klimaatklassifikasie-stelsel word dikwels in klimatologie, studies van klimaatverandering en vir 'n wye verskeidenheid van toepassings wat te doen het met die biosfeer en hidrosfeer gebruik. Dit word alreeds oor so 'n lang tydperk gebruik dat klimatoloë baie vertroud is daarmee. Die eerste kwantitatiewe klassifikasie van die wêreld se klimaat is deur die Duitse wetenskaplike Wladimir Köppen (1846-1940) reeds in 1900 bekendgestel. Hierdie werk is opgedateer deur Rudolf Geiger (1894-1981). Die Köppen-Geiger klimaatkaart het die internasionale de facto standaard geword (Kottek, Grieser, Beck, Rudolf \& Rubel, 2006: 259).
Ten einde die huidige Suid-Afrikaanse klimaat te kwantifiseer, as 'n basis, en om onder andere passiewe beginsels vir gebou-ontwerp te ondersteun, het die Wetenskaplike en Nywerheidsnavorsingsraad (WNNR) in 2010 ' $n$ baie akkurate klimaatkaart geproduseer wat op die standaard Köppen-Geiger metode gebaseer is (Figuur 1) (Conradie, Van Reenen \& Bole, 2015: 83-91). Die KöppenGeiger klimaatklassifikasie gebruik 'n samestelling van 'n maksimum van drie alfabetiese karakters wat die hoof klimaatkategorieë, die hoeveelheid reënval, en temperatuur eienskappe beskryf. Dit is gebaseer op 'n stel empiriese formules wat in Tabelle 1 en 2 beskryf word. 'n Gedetailleerde historiese datastel is verkry vanaf die SuidAfrikaanse Landbounavorsingsraad (Agrometeorology Staff, 2001). Die Arcmap Geographic Information System (GIS) is gebruik om 'n klimaatkaart saam te stel wat die formules soos deur Kottek et al. (2006: 259-263) beskryf is, te gebruik (Figuur 1).
Tabel 1 lys die formules wat gebruik is om die eerste twee letters van die klassifikasie af te lei. Die formules is essensieel funksies van droëbol temperatuur en reënval. Die jaarlikse gemiddelde temperatuur word aangedui met $\mathrm{T}_{\text {ann }}$ en die maandelikse gemiddelde temperatuur van die warmste en koudste maande deur $\mathrm{T}_{\text {max }}$ en $\mathrm{T}_{\min }$, respektiewelik. $\mathrm{P}_{\text {ann }}$ is die geakkumuleerde jaarlikse reënval en $P_{\min }$ is die reënval van die droogste maand. Die waardes $P_{\text {smin }}, P_{\text {smax }}$, $P_{\text {wmin }}$ en $P_{\text {wmax }}$ is gedefinieer as die minimum en maksimum maandelikse reënvalsyfers vir die somer en winter halfjare vir die betrokke halfrondte onder beskouing. Al die temperature is in ${ }^{\circ} \mathrm{C}$ uitgedruk, maandelikse reënval in $\mathrm{mm} /$ maand, en jaarlikse reënval, $\mathrm{P}_{\text {ann }}$, in $\mathrm{mm} / \mathrm{jaar}$.

Benewens die temperatuur- en reënvalwaardes, is 'n droogheid drumpel $P_{\text {th }}$ in $\mathrm{mm}$ ingesluit vir dorre klimate (B), wat afhang van $\left\{\mathrm{T}_{\text {ann }}\right\}$, die absolute maatstaf van die jaarlikse gemiddelde temperatuur in ${ }^{\circ} \mathrm{C}$, en die jaarlikse reënvalsiklus.

Tabel 1: Sleutel om die eerste twee letters van die Köppen-Geiger klassifikasie te bereken

\begin{tabular}{|c|c|c|}
\hline Tipe & Beskrywing & Kriteria \\
\hline A & Ekwatoriale klimate & $\mathrm{T}_{\min } \geq+18^{\circ} \mathrm{C}$ \\
\hline Af & Ekwatoriale reënwoud, ten volle vogtig & $P_{\min } \geq 60 \mathrm{~mm}$ \\
\hline $\mathrm{Am}$ & Ekwatoriale moeson & $P_{\text {ann }} \geq 25\left(100-P_{\min }\right)$ \\
\hline As & Ekwatoriale grasvlakte (savanne) met droë somer & $\mathrm{P}_{\min }<60 \mathrm{~mm}$ in somer \\
\hline Aw & Ekwatoriale grasvlakte (savanne) met droë winter & $P_{\min }<60 \mathrm{~mm}$ in winter \\
\hline B & Dorre klimate & $P_{\text {ann }}<10 P_{\text {th }}$ \\
\hline BS & Steppe klimaat & $P_{\text {ann }}>5 P_{\text {th }}$ \\
\hline BW & Woestyn klimaat & $P_{\text {ann }} \leq 5 P_{\text {th }}$ \\
\hline C & Warm matige klimate & $-3^{\circ} \mathrm{C}<\mathrm{T}_{\min }<+18^{\circ} \mathrm{C}$ \\
\hline $\mathrm{Cw}$ & Warm matige klimaat met droë winter & $\mathrm{P}_{\text {wmin }}<\mathrm{P}_{\text {smin }}$ and $\mathrm{P}_{\text {smax }}>10 \mathrm{P}_{\text {wmin }}$ \\
\hline $\mathrm{Cf}$ & Warm matige klimaat, ten volle vogtig & Nòg Cs nòg Cw \\
\hline D & Sneeuklimate & $\mathrm{T}_{\min } \leq-3^{\circ} \mathrm{C}$ \\
\hline Ds & Sneeuklimaat met droë somer & $\mathrm{P}_{\text {smin }}<\mathrm{P}_{\text {wmin }}, \mathrm{P}_{\text {wmax }}>3 \mathrm{P}_{\mathrm{smin}}$ and $\mathrm{P}_{\mathrm{smin}}<40 \mathrm{~mm}$ \\
\hline Dw & Sneeuklimaat met droë winter & $\mathrm{P}_{\text {wmin }}<\mathrm{P}_{\text {smin }}$ and $\mathrm{P}_{\text {smax }}>10 \mathrm{P}_{\text {wmin }}$ \\
\hline $\mathrm{Df}$ & Sneeuklimaat, ten volle vogtig & Nòg Ds nòg Dw \\
\hline $\mathrm{E}$ & Pool klimate & $\mathrm{T}_{\max }<+10^{\circ} \mathrm{C}$ \\
\hline ET & Toendra (mossteppe) klimaat & $0^{\circ} \mathrm{C} \leq \mathrm{T}_{\max }<+10^{\circ} \mathrm{C}$ \\
\hline
\end{tabular}


Tabel 2: $\quad$ Sleutel om die derde letter van die temperatuurklassifikasie te bereken

\begin{tabular}{|c|c|c|}
\hline Tipe & Beskrywing & Kriteria \\
\hline $\mathrm{h}$ & Warm steppe/woestyn & $\mathrm{T}_{\mathrm{ann}} \geq+18^{\circ} \mathrm{C}$ \\
\hline k & Koue steppe/woestyn & $\mathrm{T}_{\mathrm{ann}}<+18^{\circ} \mathrm{C}$ \\
\hline a & Warm somer & $\mathrm{T}_{\text {max }} \geq+22^{\circ} \mathrm{C}$ \\
\hline $\mathrm{b}$ & Warm somer & nie (a) en ten minste $4 \mathrm{~T}_{\text {mon }} \geq+10^{\circ} \mathrm{C}$ \\
\hline c & Koel somer en koue winter & nie (b) en $T_{\min }>-38^{\circ} \mathrm{C}$ \\
\hline$d$ & Uiters kontinentaal & $\operatorname{soos}(\mathrm{c})$ maar $\mathrm{T}_{\min } \leq-38^{\circ} \mathrm{C}$ \\
\hline
\end{tabular}

$$
P_{\text {th }}=\left\{\begin{array}{l}
2\left\{T_{\text {ann }}\right\} \text { as ten minste } 2 / 3 \text { van } \\
\text { die jaarlikse reënval wat in die } \\
\text { winter voorkom, } \\
2\left\{T_{\text {ann }}\right\}+28 \text { as ten minste } 2 / 3 \\
\text { van die jaarlikse reënval wat } \\
\text { in die somer voorkom, } \\
2\left\{T_{\text {ann }}\right\}+14 \text { in alle ander } \\
\text { gevalle. }
\end{array}\right.
$$

Tabel 2 toon aan hoe die addisionele temperatuurdefinisies, naamlik die derde letter, bepaal is vir dorre klimate (B), warm klimate (C), en sneeuklimate (D). In hierdie Tabel is $T_{\text {mon }}$ die gemiddelde maandelikse temperatuur in ${ }^{\circ} \mathrm{C}$.

Die Köppen-Geiger klimaatkaart toon duidelik aan waar die verskillende klimaatstreke op die oomblik voorkom. Noemenswaardige SuidAfrikaanse klimaateienskappe word hieronder beskryf en deur nommers op die kaart in Figuur 1 aangetoon:

1. Die baie warm Limpoporiviervallei, klassifikasie BWh.

2. ' $n$ Tropiese neerdaler in die noordelike dele van KwaZuluNatal provinsie, klassifikasie Aw.

3. Noord-Gauteng wat Pretoria insluit, het drie klimaatsones, naamlik BSh, Cwa and Cwb.

4. Die klimaatstreke wat trapsgewys begin by die humiede Durban, gevolg deur die Natalse middellande om uiteindelik te eindig by die Drakensberge. Dit word onderskeidelik voorgestel met die klassifikasies van $\mathrm{Cfa}, \mathrm{Cfb}$ and Cwb.

5. Die baie koue Lesotho hooglande, klassifikasie Cfb, $\mathrm{Cwb}$ and $\mathrm{Cwc}$. Laasgenoemde is amper 'n sneeuklimaat.
6. Die koue hoogliggende gebiede rondom Sutherland met ' $n$ klassifikasie van BSk.

7. Die dorre Weskusklimaatstreek noord van Kaapstad wat by Yzerfontein begin met ' $n$ klassifikasie van BSk.

8. Die smal Suidelike Kaap kondensasie kusstreek wat noord van Kaapstad begin en strek tot en met net anderkant Port Alfred het ses klimaatsones, naamlik BSk, BSh, Cfa, Cfb, Csa en Csb. (Mathews, Geyser \& Taylor, 2000: 51). Dit is die gebied waar kondensasie en skimmel 'n groot probleem is in veral lae-koste behuising.

\section{STADSBEPLANNING IN DORRE GEBIEDE}

'n Ontleding van die Köppen-Geiger kaart in Figuur 1 toon aan dat Suid-Afrika per oppervlakte op die oomblik alreeds ' $n 70.9 \%$ dorre klimaat en 'n $28.9 \%$ warm matige klimaat het. Die ekwatoriale klimaat is op die oomblik nog min met slegs $0.2 \%$ van die land se oppervlakte. Hierdie persentasies is effens anders as die historiese basis wat in Tabel 5 genoem word omdat daar ' $n$ ander datastel gebruik is (Landbou Navorsingsraad) en die tydperk is vanaf 1985 tot 2005. In die algemeen het dorre gebiede baie min reënval en die temperatuur varieer drasties tussen dag en nag. Daar is ook intense sonstraling, veral in die somer, wat Suid-Afrika baie geskik maak vir die opwekking van fotovoltaïese krag aan die positiewe kant, maar aan die ander kant moet die straling effektief beheer word in stedelike ruimtes en in geboue. Die afwesigheid van grond en plantegroei in baie dorre gebiede verminder die grond se vermoë om afloop- en stormwater te absorbeer. Daar vind dus potensieel baie gronderosie plaas. ' $n$ Hele aantal basiese oorwegings moet in ag geneem word wanneer stede in dorre gebiede beplan word. Die faktore kan in sosiale, ekonomiese en fisiese aspekte geklassifiseer word. Die huidige artikel word beperk tot fisiese oorwegings. Volgens Golany (1978: 6) bestaan daar baie min teorieë oor die keuse van terreine in dorre gebiede. ' $n$ Studie van antieke beskawings soos die Romeine toon egter aan dat daar 'n groot corpus van ondervinding is wat moderne beplanners nog steeds kan help. Vitruvius (gebore ongeveer 80-70 v.C., oorlede na 15 n.C.) dokumenteer reeds in antieke tye riglyne vir die keuse van 'n gesonde terrein vir die aanlê van 'n stad. Sy voorskrifte neem onder andere hoogte, winde, en hellingsrigting (aspect) in ag. Hy gaan verder en stel verskillende metodes voor om te verseker dat daar voldoende goeie kwaliteit water sal wees, en dokumenteer vindingryke ter plaatse toetse wat uitgevoer kan word om dit te bevestig (Morgan, 1960: 17-21, 227-242).

\subsection{Primêre vereistes vir die keuse van 'n terrein}

Die primêre vereistes vir die keuse van ' $n$ terrein vir stadsaanleg is (Golany, 1978: 3-20):

1. Daar moet genoeg ruimte wees vir die beplande bevolking.

2. Genoeg waterbronne vir daaglikse huishoudelike, industriële en dienste verbruik.

3. Toeganklikheid van vervoersisteme. 
4. Plaaslike bronne om ten minste vir 'n gedeelte van die bevolking werk te verskaf.

5. Gerieflike klimaat vir gesonde leef en werk.

Die laaste faktor is die belangrikste. Ongelukkig sal nie alle terreine aan alle faktore vir gerief voldoen nie. Die volgende faktore beïnvloed gerief.

\subsubsection{Lugtemperatuur}

Die kombinasie van lugtemperatuur en relatiewe humiditeit is baie belangrik vir gerief (Golany, 1978: 7). Dit word duidelik in Figuur 4 geïllustreer. 'n Slegte keuse vir ' $n$ terrein is aan die basis van 'n heuwel. Die temperatuur is gewoonlik hoër as bo-aan dieselfde helling weens die verhoogde lugdruk en gepaardgaande verhoging in temperatuur (adiabatic heating). Nog 'n slegte ligging is 'n vallei waar die lug kan oorverhit en temperatuurinversie kan voorkom. Hierdie effek word dikwels in Pretoria gedurende die wintermaande ondervind wanneer daar omtrent geen wind is nie en die rookmis dikwels in die laagliggende moot (vallei in Pretoria tussen twee parallele heuwelreekse) opbou. Die belanrikste manier om windtemperatuur te verminder, is om 'n gunstige verhouding te hê van skaduryke ruimtes teenoor ruimtes wat aan die son blootgestel is. In hierdie opsig kan genoegsame bome 'n groot rol speel.

\subsubsection{Relatiewe humiditeit (vogtigheid)}

In dorre gebiede soos die weskus van Suid-Afrika is hellings wat na die see gedraai is beter as in die teenoorgestelde rigting omdat die wind oor die koue water help om die uitermate droogheid te verlig (Olgyay, 2015: 51-52, 146-152). Gedurende die wintermaande is die lug uitermate droog in binnelandse stede soos Pretoria en Johannesburg. Hier is ook nie groot damme wat verligting sou kon gebring het nie.

\subsubsection{Grondstruktuur}

Die kombinasie van lae humiditeit, hoë temperatuur en groot variasie tussen dag- en nagtemperature beïnvloed die geomorfologie en landskap van dorre gebiede (Golany, 1978: 7-8). Hierdie kombinasie produseer sand wat algemeen in hierdie gebiede voorkom. Die afwesigheid van plantegroei maak die sand onstabiel wat dan maklik deur die wind weggewaai kan word. Die stofstorms kan die onderhoud van geboue nadelig beïnvloed. Dit is op die oomblik reeds die situasie in die groot sentrale gebiede van Suid-Afrika soos die Karoo, Vrystaat, en Noord-Kaap.

\subsubsection{Blootstelling aan sonstraling}

Die intense sonstraling speel 'n groot rol in Suid-Afrika. Beplanners moet die oriëntasie van terreine ten opsigte van die son versigtig kies. Noordelike hellings ontvang die mees intense sonstraling gedurende die dag, terwyl suidelike hellings die minste ontvang. Terreine met oos- of weshellings ontvang minder straling as die wat noord wys, maar baie meer as die wat suid wys. Oostelike hellings ontvang sonstraling tot die middag, terwyl westelike hellings sonstraling in die namiddag ontvang, wanneer die sonstraling op sy hoogste is. Volgens Golany (1978: 8) behoort die keuse van ' $n$ helling in die volgende voorkeurorde te wees:

1. Suidelike helling (noordelike helling in die noordelike halfrond).

2. Oostelike helling.

3. Westelike helling.

4. Noordelike helling (suidelike helling in die noordelike halfrond).

\subsubsection{Hoogte bo seespieël}

Die temperatuur verminder en die relatiewe humiditeit verhoog met hoogte bo seespieël. 'n Hooggeleë terrein maak dit koeler en is dus geriefkliker. Die effek word baie mooi geïllustreer deur die verskil in temperatuur op 'n warm dag tussen Johannesburg en Pretoria. Die verskil in hoogte tussen die twee stede is ongeveer $460 \mathrm{~m}$. Wanneer die adiabatiese vervaltempo bereken word, kan dit teoreties 'n verskil van tot $4.5^{\circ} \mathrm{C}$ op 'n gegewe dag beteken. In die praktyk is dit gewoonlik 'n verskil van $2^{\circ} \mathrm{C}$.

\subsubsection{Reënval}

Op die oomblik is Suid-Afrika alreeds 'n droë land wat gekenmerk word deur lang en intense droogtes (Conradie, Van Reenen \& Bole, 2015: 83-91). Indien dit wel reën, vind intense erosie en grondverskuiwings dikwels plaas. Groot hoeveelhede slik, modder en rotse dreineer na die hoof waterweë in 'n kort tyd wat baie gevaarlik is. Die onlangse vloede in Durban illustreer dit. In Suid-Afrika is die volgende aspekte belangrik (Golany, 1978: 11):

1. Die natuurlike dreinering van terreine moet skielike intense reënval kan hanteer.

2. Die terrein moet nie gekies word op vlaktes wat van tyd tot tyd oorstroom of langs droë riviere loop nie.

3. Die stormwaterdreinering in dorre gebiede moet ontwerp word om vinnige hoë intensiteit afloop te hanteer na storms.

Op 25 Januarie 1981 is ' $n$ groot deel van die dorp Laingsburg binne minute weggespoel deur een van die mees verwoestende fratsvloede ooit, wat in die Groot-Karoo voorgekom het. $\mathrm{Na}$ 'n wolkbreuk in die noord-oostelike hinterland suid van die Komsberg het 'n wal van water 'n paar meter hoog langs die Buffelsrivier afgestorm en alles in sy pad weggevee. Mense en hul besittings was meegesleur en onder die slik begrawe. Argeoloë skat dat daar ongeveer elke 100 jaar so 'n fratsvloed te wagte kan wees.

\subsubsection{Toeganklikheid}

Toeganklikheid dwarsdeur die jaar is belangrik. Sommige skrywers argumenteer dat die ontwikkeling van lugvervoer 'n prioriteit behoort te wees om goeie verbindings met afgeleë stede of dorpe in dorre gebiede te verseker (Golany, 1978: 11). Stede in Suid-Afrika het egter anders ontwikkel. Pad- en spoornetwerke het lank voor lugvervoer ontwikkel. 'n Kommerwekkende tendens is egter die lae digtheid van stede soos Pretoria. Pretoria het van die laagste stedelike bevolkingsdigthede ter wêreld. Die bevolkingsdigtheid, gebaseer op die 2011 sensus, varieer van 1156 persone $/ \mathrm{km}^{2}$ in Winterveld tot 17459 persone/ $\mathrm{km}^{2}$ in Sunnyside. 
Meer gegoede woonbuurte soos Garsfontein en Moreletapark het bevolkingsdigthede van onderskeidelik 2672 persone $/ \mathrm{km}^{2}$ en 2 753/km². Dit maak die pad- en dienste-infrastruktuur geweldig duur omdat die afstande so groot is. Die reisafstande na en van werk af word ook geweldig vêr wat aanleiding gee tot 'n groter per kapita koolstofspoor. Volgens The International Bank for Reconstruction and Development \& World Bank (2010: 27) kan verhoogde stadsdigtheid energieverbruik drasties verminder. Volgens dieselfde verslag is die stadsbeplanning en mobiliteit bepalend vir $\mathrm{CO}_{2}$ vrystellings. Kompakte stede is meer volhoubaar as uitgestrekte lae-digtheid stede.

\subsubsection{Waterbronne}

Die bestuur van stormwater en die beskikbaarheid van skoon drinkbare water word toenemend 'n groter probleem in Suid-Afrika, as gevolg van periodiese droogtes en 'n groeiende bevolking. Dit het nou tyd geword om afvalwater direk te herwin soos wat Windhoek in Namibië al sedert 1968 doen (Haarhoff \& Van der Merwe, 1996: 25-35).

\section{KLIMAATVERANDERING}

Stede dra baie by tot kweekhuisgasvrystellings. Op die oomblik bly die helfte van die wêreld se bevolking in stede. Dit gaan waarskynlik tot $70 \%$ verhoog teen 2050 . Stede verbruik so veel as $80 \%$ van alle energieproduksie wêreldwyd (The International Bank for Reconstruction and Development \& World Bank, 2010: 15).

Ten einde moontlike klimaatverandering te beskryf, is kweekhuisgas-vrystellingscenario's teen die middel 1990s deur die Intergovernmental Panel on Climate Change (IPCC) ontwikkel (IPCC, 2000: 3-5). Die scenario ontwikkeling is op twee vlakke met die vier abstrakte temas boaan en ses meer gedetaileerde afhanklike scenario's op 'n laer vlak. Die temas is ontwikkel om konteks aan die scenarios te gee. Elke tema verteenwoordig verskillende demografiese, sosiale, ekonomiese, tegnologiese, en omgewingsontwikkelings wat deur sommige wetenskaplikes as positief en deur ander as negatief beskou kan word (Figuur 2). Elke scenario verteenwoordig die dryfkragte en vrystellings in die scenario-literatuur om die huidige begrip en kennis oor die onderliggende onsekerhede te beskryf. Verder verteenwoordig elke scenario 'n spesifieke kwantitatiewe interpretasie van een van die temas. Al die soortgelyke scenario's wat op dieselfde tema gebaseer is, word 'n familie van scenario's genoem. Wanneer klimaatverandering bestudeer word, word dit in terme van een of meer van dié scenario's gedoen en bereken met gekoppelde globale klimaatsmodelle (GGKMe) (coupled global climate models).

Die A1 tema en scenariofamilie (Figuur 2) beskryf 'n toekomstige wêreld van snelle ekonomiese groei, 'n globale bevolking wat sy piek in die middel van die eeu bereik en dan geleidelik begin afneem. Daar is die vinnige invoer van nuwe en meer effektiewe tegnologieë. Grootskaalse onderliggende temas is die samesmelting (convergence) van streke, opbou van kapasiteit en verhoogde kulturele en sosiale interaksies. Daar is ook 'n aansienlike vermindering in die per kapita inkomsteverskille tussen verskillende streke. Die A1 scenariofamilie is verder ontwikkel in drie groepe wat alternatiewe energiesisteme beskryf. $\mathrm{A} 1 \mathrm{FI}$ is fossielbrandstof intensief, A1T is nie-fossielbrandstof gebaseer, terwyl A1B 'n gebalanseerde gebruik van alle energiebronne verteenwoordig.

Die A2 tema en scenariofamilie (Figuur 2) beskryf 'n baie heterogene wêreld. Die onderliggende tema is selfstandigheid en die bewaring van plaaslike identiteit. Die bevolkingsvrugbaarheidspatrone tussen streke konvergeer baie stadig, wat veroorsaak dat die wêreldbevolking aanhou groei. Ekonomiese ontwikkeling is primêr streeksgeoriënteerd en die per kapita groei en tegnologiese verandering is meer gefragmenteerd en stadiger as in die ander temas.
Die B1 tema en scenariofamilie (Figuur 2) beskryf 'n wêreld met 'n wêreldbevolking wat 'n piek teen die middel van die eeu bereik en daarna afneem soos in die A1 tema. Daar is egter vinnige veranderings in ekonomiese strukture tot 'n meer diens- en inligtinggeoriënteerde ekonomie, met minder gebruik van materiaal, en die invoer van skoon en effektiewe tegnologieë. Die klem is op globale oplossings vir ekonomiese, sosiale, en omgewingsvolhoubaarheid insluitende gelykheid, maar sonder addisionele klimaatsinisiatiewe. Laasgenoemde beteken dat geen scenario's ingesluit is wat eksplisiete implementasie van die Verenigde Nasies se Framework on Climate Change of die vrystellingsteikens (soos die van $\mathrm{CO}_{2}$ ) van die Kyoto Protocol aanvaar nie.

Die B2 tema en scenariofamilie (Figuur 2) beskryf 'n wêreld met die klem op plaaslike oplossings vir ekonomiese, sosiale, en omgewingsvolhoubaarheid. Dit is 'n wêreld met 'n deurlopende vermeerdering in globale bevolking, maar teen 'n stadiger tempo as met A2. Daar is intermediêre vlakke van ekonomiese ontwikkeling en stadiger en meer diverse tegnologiese verandering as met $\mathrm{B} 1$ en $\mathrm{A} 1$ temas. Hierdie scenario is meer georiënteerd tot omgewingsbeskerming en sosiale gelykheid en fokus op plaaslike en streeksvlakke.

Opinies verskil oor presies wat die effek van klimaatverandering in SuidAfrika gaan wees omdat dit 'n uiters komplekse onderwerp is. Hieronder word twee onlangse kwantitatiewe klimaatveranderingvooruitskattings bespreek wat verskillende perspektiewe gee.

In die eerste studie het Rubel \& Kottek (2010: 135-141) in 2010 omvattende studies onderneem om die wêreldwye klimaatverandering te karteer. Twee globale datastelle van klimaatwaarnemings is gebruik om die Köppen-Geiger klimaatstreke te bereken. Beide stelle was beskikbaar met 'n 0.5 grade (breedtegraad/ lengtegraad) akkuraatheid met maandelikse tydlynresolusie. Die eerste datastel is deur die Climatic 


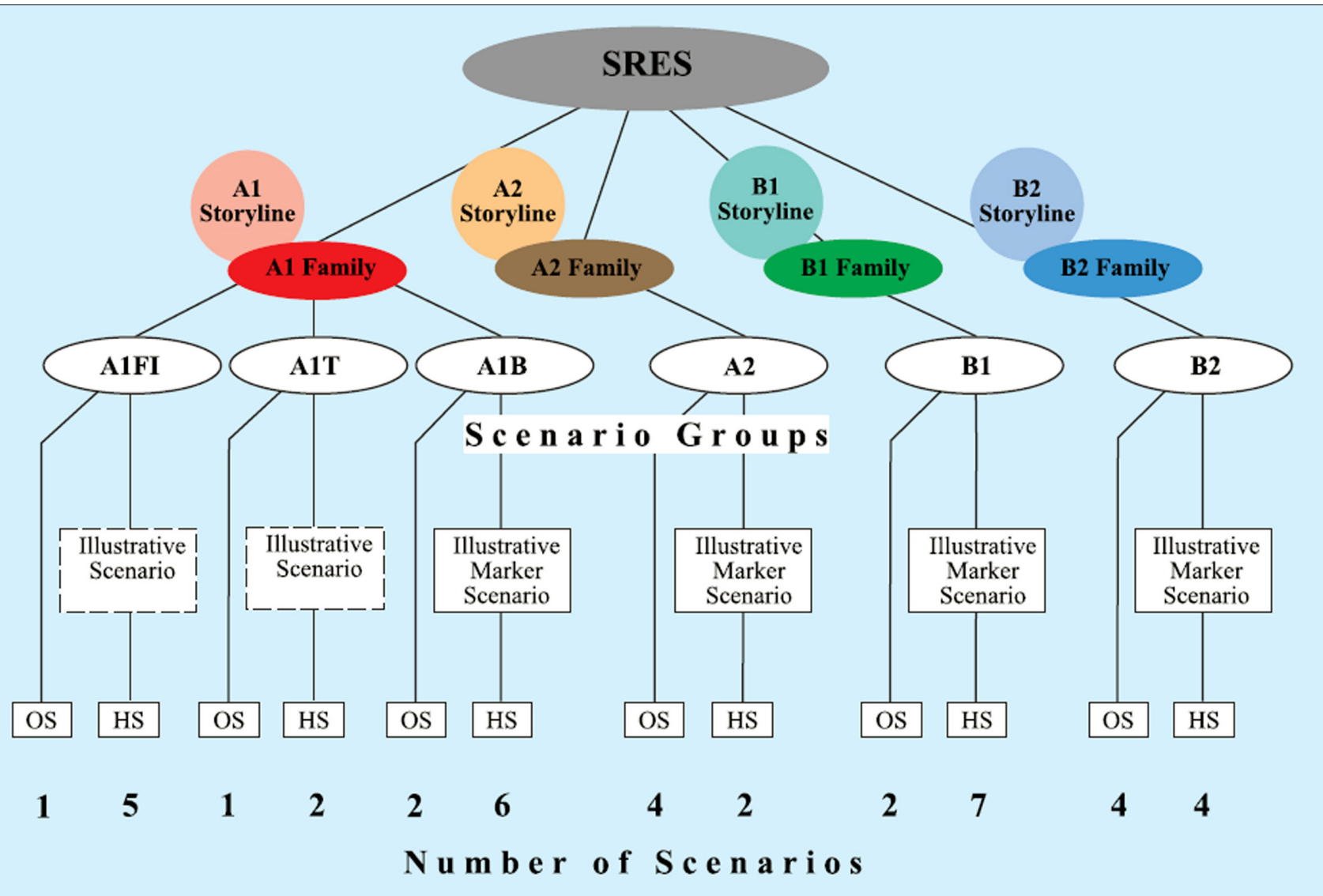

Figuur 2: Skematiese voorstelling van die verskillende IPCC Special Report Emissions Scenarios (SRES). Dit sluit vier temas, vier scenariofamilies en ses scenariogroepe in.

Bron: $\quad$ IPCC, 2000: 4

Research Unit (CRU) van die University of East Anglia voorsien. Die datastel het nege klimatologiese veranderlikes, waarvan slegs temperatuur gebruik is. Hierdie datastel is bekend as die CRU TS 2.1 en het wêreldwye dekking, met die uitsondering van Antartika. Die tweede datastel is deur die Global Precipitation Climatology Centre (GPCC) van die Duitse Weerdiens voorsien. Dit is bekend as die GPCC Full Data Reanalysis Version 4 vir 1901-2007. Hierdie data dek alle globale landoppervlaktes, met die uitsondering van Groenland en Antartika.

Globale temperatuur- en reënvalsyfer-projeksies vir die periode 2003-2100 van die Tyndall Centre for Climate Change Research datastel (TYN SC 2.03) is gebruik. Dit bestaan uit 'n totaal van 20 Globale Klimaat Model (GKM) simulasies, gekombineer met vier moontlike toekomstige IPCC Special Report Emissions Scenarios (SRES) (IPCC, 2000: 3-5) vrystellingscenario's soos hierbo beskryf met behulp van vyf klimaatsmodelle wat die nuutste idees en eienskappe bevat (Tabel 3). Die TYN SC 2.03 datastel neem die $\mathrm{A} 1 \mathrm{FI}, \mathrm{A} 2$, B1 en B2 scenario's in ag (Figuur 2).

Die resultaat van hierdie simulasies ten opsigte van die IPCC A1FI en B1 simulasies oor die periode 1976-2000 tot en met 2076-2100 was as volg.

Die mees sigbare klimaatverandering was in die noordelike halfrond in die $30^{\circ}-80^{\circ}$ breedtegraad band.

Die A1FI en B1 scenario's is die twee uiterstes, maar illustreer die punt duidelik. In die tydperk 1976-2000 het $29.14 \%$ van die globale landoppervlakte 'n Köppen-Geiger klassifikasie van $\mathrm{B}$, gevolg deur $21.62 \%$ D klimate, $19.42 \%$ A klimate, $15.15 \%$ E klimate, en $14.67 \%$ C klimate. In die A1FI scenario vir die periode 2076-2100 toon die ensemble gemiddelde (Tabel 3) aan dat die A klimate $22.46 \%$, B klimate $31.82 \%$, C klimate $15.2 \%$, E klimate $11.04 \%$, en D klimate $19.48 \%$ sal wees.
Die B1 vrystellingsscenario toon aansienlik kleiner verskuiwings aan. In die B1 scenario vir die periode 2076-2100 toon die ensemble gemiddelde (Tabel 3) aan dat A klimate $21.69 \%$, B klimate $30.07 \%$, C klimate $14.29 \%$, D klimate $21.75 \%$, en $\mathrm{E}$ klimate $12.21 \%$ sal wees.

In die tweede studie het Engelbrecht \& Engelbrecht (2016: 247-261) 'n alternatiewe ensemble van GGKMe gebruik (Tabel 3). Hierdie simulasies is spesifiek vir Suidelike Afrika uitgevoer en weereens is KöppenGeiger klimaatkaarte gebruik om die klimaatverandering voor te stel. In alle gevalle is die A2 scenario van die IPCC gebruik. Volgens Engelbrecht \& Engelbrecht (2016: 247) is A2 (amper so erg as die A1FI scenario) volgens hul navorsing waarskynlik die naaste aan wat op die oomblik aan die gebeur is.

In hierdie studie was die benadering anders as in die eerste studie wat hierbo beskryf is. Die navorsers het $1^{\circ} \mathrm{C}$ tot $3^{\circ} \mathrm{C}$ globale temperatuurverhogings 
Tabel 3: Globale klimaatverandering model simulasies gebruik in die twee klimaatverandering simulasies

\begin{tabular}{|l|l|l|}
\hline \multicolumn{1}{|c|}{$\begin{array}{c}\text { Beskrywing } \\
\text { hadCM3 }\end{array}$} & Rubel \& Kottek (2010: 138) & \multicolumn{1}{|c|}{ Engelbrecht \& Engelbrecht (2016: 249) } \\
\hline Hadley Centre Coupled Model Version 3 & HadCM3 & HadCM3 \\
\hline National Center for Atmospheric Research-Parallel Climate Model & NCAR-PCM & \\
\hline Second Generation Coupled Global Climate Model & CGCM2 & \\
\hline Australian Industrial Research Organization - Climate Model Version 2 & CSIRO2 & \\
\hline Australian Industrial Research Organization - Climate Model Version 3.5 & & CSIRO3.5 \\
\hline European Centre Model Hamburg Version 4 & ECHam4 & \\
\hline National Oceanic and Atmospheric Administration & & GFDL-CM2.0 \\
\hline National Oceanic and Atmospheric Administration & & GFDL-CM2.1 \\
\hline German Ocean Model & & ECHAM5/MPI \\
\hline Japanese Agency for Marine-Earth Science and Technology & & MIROC3.2-medres \\
\hline
\end{tabular}

Tabel 4: Die verwagte jaar wanneer die globale temperatuur $1^{\circ} \mathrm{C}, 2^{\circ} \mathrm{C}$ en $3^{\circ} \mathrm{C}$ bereik vir elkeen van die simulasies

\begin{tabular}{|l|c|c|c|}
\hline \multicolumn{1}{|c|}{ Engelbrecht \& Engelbrecht(2016: 249) } & $1^{\circ} \mathrm{C}$ & $2^{\circ} \mathrm{C}$ & $3^{\circ} \mathrm{C}$ \\
\hline HadCM3 & 2032 & 2058 & 2079 \\
\hline CSIRO3.5 & 2021 & 2051 & 2071 \\
\hline GFDL-CM2.0 & 2029 & 2058 & 2078 \\
\hline GFDL-CM2.1 & 2026 & 2064 & 2083 \\
\hline ECHAM5/MPI & 2037 & 2061 & 2077 \\
\hline MIROC3.2-medres & 2019 & 2054 & 2070 \\
\hline
\end{tabular}

Tabel 5: Die persentasie oppervlakte beslaan deur die verskillende Köppen-Geiger klimate in Suidelike Afrika ten opsigte van die historiese basis (1961-1990) (Verwerking van Engelbrecht \& Engelbrecht, 2016: 251 se resultate)

\begin{tabular}{|l|c|c|c|c|}
\hline \multicolumn{1}{|c|}{$\begin{array}{c}\text { Eerste letter van Köppen-Geiger } \\
\text { klimaatklassifikasie }\end{array}$} & Huidige basis & $1^{\circ} \mathrm{C}$ & $2^{\circ} \mathrm{C}$ & $3^{\circ} \mathrm{C}$ \\
\hline A & 1.7 & 2.2 & 2.9 & 4.0 \\
\hline B & 77.6 & 78.9 & 82.6 & 82.7 \\
\hline C & 20.7 & 18.9 & 14.6 & 13.4 \\
\hline
\end{tabular}

as merkers geneem en dan vervolgens die lokale effek op Suid-Afrika bereken, wat blyk om aansienlik hoër te wees as die globale gemiddelde (Tabel 4).

Die meerderheid van hierdie simulasies toon aan dat Suid-Afrika in die algemeen 'n droër en aansienlik warmer toekoms gaan hê (Tabel 5). Dit is duidelik uit hierdie simulasies dat die warm woestynsone (BWh) aansienlik suidwaarts gaan uitbrei en tot 'n mindere mate ooswaarts. Simulasies toon ook aan dat 'n drastiese temperatuurverhoging van $4^{\circ} \mathrm{C}$ tot $6^{\circ} \mathrm{C}$ in Suid-Afrika verwag kan word in die geval van 'n $3^{\circ} \mathrm{C}$ globale temperatuurverhoging.

\section{INVLOED VAN KLIMAATVERANDERING OP BESTAANDE EN NUWE STEDE}

\subsection{Stedelike Hitte-Eiland (SHE)-effek}

Soos stedelinge weet, is dit dikwels warmer in die stad as in die omliggende landelike areas veral gedurende mooiweer en gedurende die nag. Die term 'hitteeiland' word gebruik omdat die stad letterlik in 'n see van koeler landelike lug lê. Navorsers soos McCarthy, Best \& Betts (2010: 1) beweer dat die verwarmingstendens van die SHE-effek in sommige plekke dieselfde of selfs meer is as die wat deur kweekhuisgasse veroorsaak word. Stedelike areas is 'n groot bron van dioksiedvrystelling wat bydra tot kweekhuisgasgedrewe klimaatverandering. Klimaatverandering dra by tot ' $n$ groter toename in warm nagte vir stedelike gebiede as die aangrensende landelike gebiede (McCarthy, Best \& Betts, 2010: 1). Stedelike digtheid en ruimtelike organisasie is belangrike faktore wat energieverbruik beïnvloed veral met betrekking tot vervoer en geboudienste (The International Bank for Reconstruction and Development \& World Bank, 2010: 19). Volgens dieselfde verslag dra Suid-Afrika as 'n geheel 9.92 tCO e/kapita in 1994 en Kaapstad $7.6 \mathrm{tCO}_{2}$ e/kapita in 2005, en Johannesburg $9.9 \mathrm{tCO}_{2} \mathrm{e} /$ kapita (geskatte syfer) by. Dit is baie minder as die bydrae van lande soos Australië (25.75), Verenigde State van Amerika (23.59), en Kanada (22.65) en meer as lande soos Argentinië (7.64), Brasilië (4.16), en Switserland (6.79).

Die SHE-effek in Londen is eerste deur Luke Howard (1833: 2) in sy noukeurige stedelike klimaatstudies van 1806-1830 waargeneem en in sy boek The climate of London gedokumenteer. Howard is ook wyd bekend as die vader van 'n praktiese wetenskaplike wolkklassifikasie wat nog steeds vandag gebruik word. Gebaseer op sy waarnemings vermeld hy "But the temperature of the city is not to be considered as that of the climate; it partakes too much of an artificial 
warmth, induced by its structure, by a crowded population, and the consumption of great quantities of fuel in fires". Sy analise is die eerste van twee verwante aspekte, naamlik die stedelike kontaminasie van weerkundige rekords en die grootte en oorsaak van die SHE-effek. Meer onlangs is ander SHE-navorsing ook gedoen soos 'n studie oor koel- en groendakke in Singapoer om die effek van SHE te verminder (XianXiang \& Norford, 2016). Clay, Guan, Wild, Bennett, Vinodkumar \& Ewenz (2016) het die SHE in Adelaide, SuidAustralië, vroegoggend bestudeer met behulp van bewegende voertuie. Hendel, Gutierrez, Colombert, Diab \& Royon (2016: 43-58) het die gebruik van benatting van sypaadjies in Parys, Frankryk bestudeer as 'n SHE-verminderingstegniek. In 'n meer ambisieuse studie het Ward, Lauf, Kleinschmit \& Endlicher (2016) die effek van hittegolwe en SHE in Europa bestudeer en spesifiek die aandrywers van SHE beoordeeel. Li, Li, Middel, Harlan, Brazel \& Turner (2016) het die SHE en grondsamestelling in Phoenix, Arizona bestudeer. Howard se analise kan in moderne navorsing oor SHE beskryf word in terme van die verskillende energiebasisse wat betrokke is. Die hoeveelheid energie onder die stedelike daklyn kan as volg in 'n formule uitgedruk word (Howard, 1833: 8): ${ }^{1}$

$Q^{*}+Q_{F}=Q_{H}+Q_{E}+\Delta Q_{S}$

waar:

$Q^{*}$ is die netto bestraling

$Q_{F}$ is die hoeveelheid hitte wat deur antropogeniese (menslike) aktiwiteite bygevoeg word

$Q_{H}$ is die aanvoelbare hitte uitruiling

$Q_{E}$ is die latente hitte uitruiling

$\Delta Q_{S}$ is die energie wat bygevoeg of weggeneem word van die stedelike struktuur

Die netto stralingsterm kan opgebreek word in son (kortgolf) en aard (langgolf) stralingskomponente.

$Q^{*}=K^{*}+L^{*}$

1 In die voorwoord van die IAUC uitgawe van Howard se 1833 boek.
Navorsing het aangetoon dat die SHE-effek die sterkte gedurende die nag is onder kalm toestande met 'n helder lugruim. Onder hierdie toestande is terme wat turbulensie vereis, naamlik

$\left(Q_{H}, Q_{E}\right)$, op 'n minimum en daar is geen sonstraling teenwoordig nie. Verder, met 'n paar uitsonderings, is $Q_{F}$ redelik onbenullig. Onder hierdie omstandighede kan die stedelike energie-formule vereenvoudig word tot:

$L^{*}=\Delta Q_{S}$

Bogenoemde impliseer dat, wanneer die stedelike temperatuureffek die grootste is, is daar verkoeling wat deur die verlies van langgolfstraling in die lug plaasvind wat gekanselleer word deur die onttrekking van hitte uit materiale wat dit gedurende die dag opgegaar het. In stede het die strukture onder die daklyn (gebou-mure en straatoppervlaktes) 'n beperkte blootstelling aan die lugruim en gevolglik word die langgolfverkoeling $\left(L^{*}\right)$ aansienlik gekortwiek. Verder is die stedelike konstruksiemateriale ondeurdringbaar en dig. Sulke materiale het hoë termiese geleiding en hitte stoorkapasiteite, wat die hitte wat gedurende die dag opgebou is beskikbaar het vir vrystelling gedurende die nag.

Howard (1833: 2-3) het op hierdie stadium reeds ' $n$ gemiddelde SHE-effek van tussen $0.816^{\circ} \mathrm{C}$ en $0.977^{\circ} \mathrm{C}$ verwarming in Londen waargeneem. Gedurende die 1960s is 'n gemiddelde verskil van tussen $4^{\circ} \mathrm{C}-6^{\circ} \mathrm{C}$ in nagtemperatuur tussen die middestad van Londen en die omliggende landelike gebiede waargeneem. Meer onlangs het klimatoloë meer ekstreme SHE-intensiteite van meer as $7^{\circ} \mathrm{C}$ waargeneem. Gedurende die hittegolf van Augustus 2003 is 'n SHE-effek van $9^{\circ} \mathrm{C}$ waargeneem in Londen (Mayor of London, 2006: 7).

Die SHE-effek word veroorsaak deur die berging van sonenergie in die harde stedelike konstruksiemateriale. Hierdie energie word dan in die atmosfeer gedurende die nag vrygestel. Figuur 3 illustreer die drastiese verskil in temperatuur tussen plantegroei en harde ondeurdringbare oppervlaktes. Figuur 3 is ' $n$ infrarooifoto wat met 'n FLIR E4 kamera op 8 April 2016 om $12 \mathrm{~h} 15$ geneem is. Die temperatuur wissel hier tussen $39.3^{\circ} \mathrm{C}$ en $-1.7^{\circ} \mathrm{C}$. Laasgenoemde lae waarde is waarskynlik die temperatuur van die wolke wat ook in die foto sigbaar is. Hierdie wolke het moontlik bo die vriesvlak gevorm. Alhoewel dit 'n relatiewe koel herfsdag was, is dit duidelik uit die temperatuurprofiel hoe groot die verskil in temperatuur tussen die mensgemaakte strukture (gebou, dak en rypad) en die plante (grasperk en bome) is. Op ' $n$ baie warm dag of tydens 'n hittegolf gaan die effek natuurlik baie meer drasties wees. Die totale hitte-opbou in 'n stad soos Pretoria met baie asfaltoppervlaktes (paaie), geboue en ander harde oppervlaktes is enorm.

\subsection{Hoe kan die SHE bestuur word?}

Die SHE-effek is 'n komplekse probleem wat moeilik is om reg te stel in bestaande stede. Beleid en regulasies om die effek te verminder, moet ' $n$ balans vind tussen die nodigheid om hitte te bestuur op gebou, buurt (voorstad) en stedelike skaal, met in ag neming van die aard van die ontwikkeling soos nuut teenoor oud en wat realisties haalbaar is. Die hoofoorsaak van SHE is dat verstedeliking die natuurlike balans tussen plantaardige en harde ondeurdringbare oppervlaktes versteur. Die fundamentele strategie vir die vermindering van SHE moet fokus op absorpsie en vrystelling van hitte vanuit die stedelike omgewing en die verandering in balans tussen die toedeling van natuurlike energie tussen verhitting en verkoeling in die stad.

Om die SHE se vorm en intensiteit te bestuur, vereis ' $n$ verandering in die eienskappe van grondbedekkings vir groot gedeeltes van die stad. Dit is baie moeilik prakties uitvoerbaar. Daar is egter baie geleenthede om die mikroklimaat te verander. Effektiewe strategieë wat binne-in die stad toegepas kan word, sluit in koel dakke, groen dakke, aanplant van bome/plantegroei, en koel sypaadjies of selfs paaie.

Daar kan drie vlakke van ingryping onderskei word, naamlik gebou-, buurt-, en stadsvlak. 


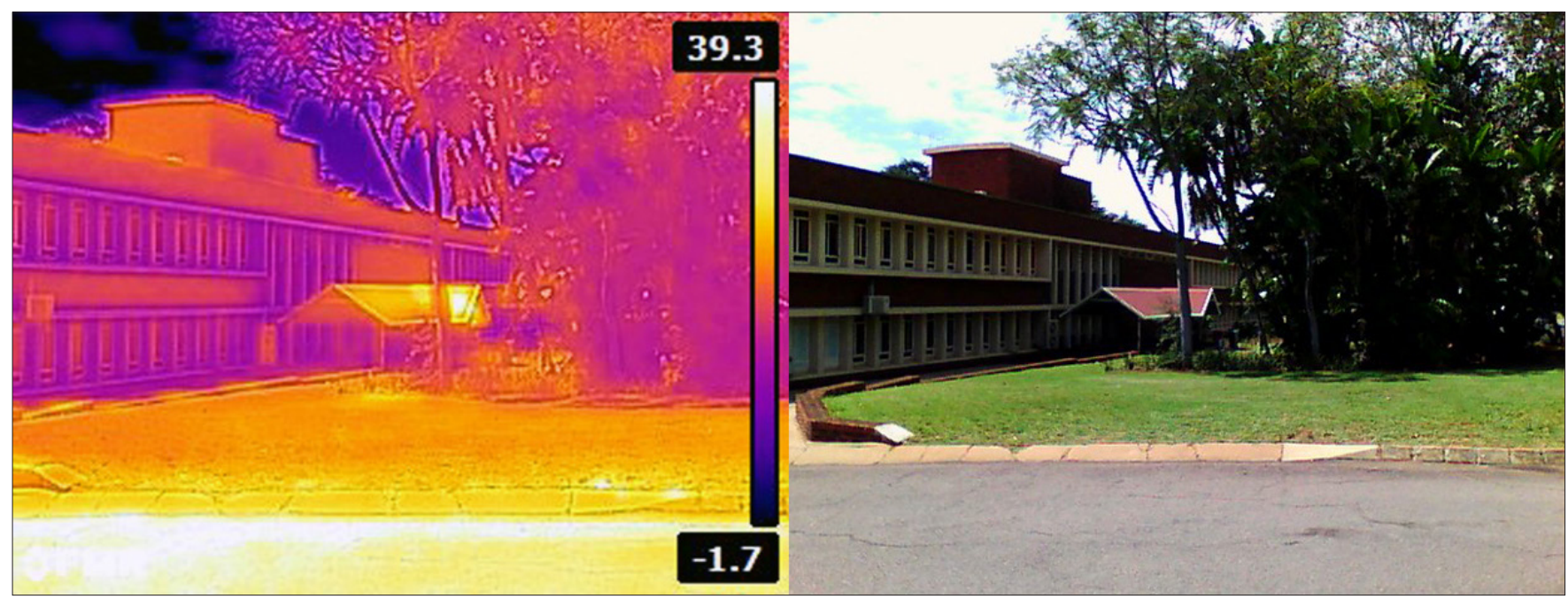

Figuur 3: Infrarooi-foto geneem by die WNNR met 'n FLIR E4 op 8 April 2016, om 12h15. Die linkerkant toon die oppervlaktemperature aan en die regterkant wat visueel sigbaar is. Die groot variasie in temperatuur is duidelik sigbaar

Bron: Outeur

Met geboue is die belangrikste faktore oriëntasie (noord in die suidelike halfrond) en korrekte sonbeskerming. Laasgenoemde is die belangrikste faktor in 'n warm land soos Suid-Afrika (Tabelle 6 en 7). Die basiese beginsel is dat die son kan help om geboue in die winter warm te maak en dus toegelaat kan word in die gebou, maar in die warmste maande moet die gebou en veral die vensters teen direkte sonindringing beskerm word. Daar is verskillende tegnieke wat vir die verskillende fasades effektief is. By noordelike fasades is horisontale sonbeskerming effektief, terwyl vertikale vinne (projeksies) die beste werk vir oos- en wesfasades omdat die son hierdie fasades redelik horisontaal tref. In die somer is daar selfs sonbeskerming nodig vir die suidelike fasades omdat die son suid van oos opkom en suid van wes ondergaan. Dit is selfs die geval vir 'n suidelike stad soos Kaapstad. Die gebruik van meer plante en bome in strate is 'n goeie maatreël om SHE te verminder. Straatbome is die effektiefste om die lokale buitetemperatuur te verminder deur hul kombinasie van skaduwee en verdampingsverkoeling. Die opinie word ook uitgespreek dat strate ten minste tweekeer so wyd moet wees as wat die geboue hoog is om goeie ventilasie te verskaf en die stedelike kloofeffek te vermy (Van Hove et al.,
2014: 52-53). Op stad- en streekvlak, veral gedurende hittegolwe, is parke baie belangrik. Parke is soos koel eilande binne-in die stad. Indien parke met verskillende mikroklimate uitgelê word, kan die stedeling gaan waarheen hy/sy gemaklik voel. In streke met hoë reënval kan parke ook dien as waterbuffers.

\subsection{Toepaslike maatreëls in gebou-ontwerp}

Talle navorsingsprojekte by die WNNR (Nice, Kumirai, Conradie \& Grobler, 2015: 175-184) het onomwonde bewys dat passiewe ontwerpbeginsels om aangename en energie-effektiewe geboue te ontwerp in warm klimate soos Suid-Afrika, soos die gebruik van natuurlike ventilasie, heeltemal haalbaar is in Suid-Afrikaanse klimate.

Een van die toeganklikste metodes wat gebruik kan word om die korrekte passiewe gebou-ontwerptegnieke te bepaal, is die bioklimatologiese kaart wat met 'n psigometriese kaart gekombineer word as 'n oorlegging (Figuur 4). Bioklimatologiese ontwerp word gebruik om potensiële passiewe gebou-ontwerpstrategieë te bepaal wat natuurlike energiebronne gebruik en sodoende energiegebruik verminder (Visitsak \& Haberl, 2004: 1-11). Hierdie benadering om binnenshuise aangenaamheid te verseker, is oorspronklik deur
Olgyay (2015: 14-31) alreeds in 1963 ontwikkel.

Givoni en Milne (1979: 96-113) het probleme met die oorspronklike Olgyay kaart opgelos soos deur in plaas van 'n vierkantige kaart met humiditeits- en temperatuurasse eerder die standaard psigometriese kaart te gebruik wat veral deur meganiese ingenieurs gebruik word. Die Givoni-Milne kaart word op die oomblik deur sommige argitekte gebruik. Gebouenergieprogrammatuur soos Ecotect het ' $n$ ingeboude psigometriese kaart met 'n vereenvoudigde Givoni-Milne oorlegging. Ecotect stel ontwerpers in staat om gebou-energieprestasie te simuleer in die vroeë fases van konseptuele ontwerp. Dit kombineer analise funksies met 'n interaktiewe vertoon wat die analitiese resultate direk binne die konteks van die model vertoon.

Wanneer 'n klimaatlêer met uurlikse temperatuur- en humiditeitdata vir 'n hele tipiese jaar vir 'n betrokke stad beskikbaar is, kan daar met behulp van dié programmatuur 'n oorlegging geskep word op die agtergrond soos in Figuur 4 geïllustreer. Die programmatuur bepaal dan hoeveel ure binne die betrokke genoemde strategiesones val, soos aangetoon met syfers aan die linkerkant van Figuur 4 en verklaring aan die regterkant van genoemde figuur. Dit 


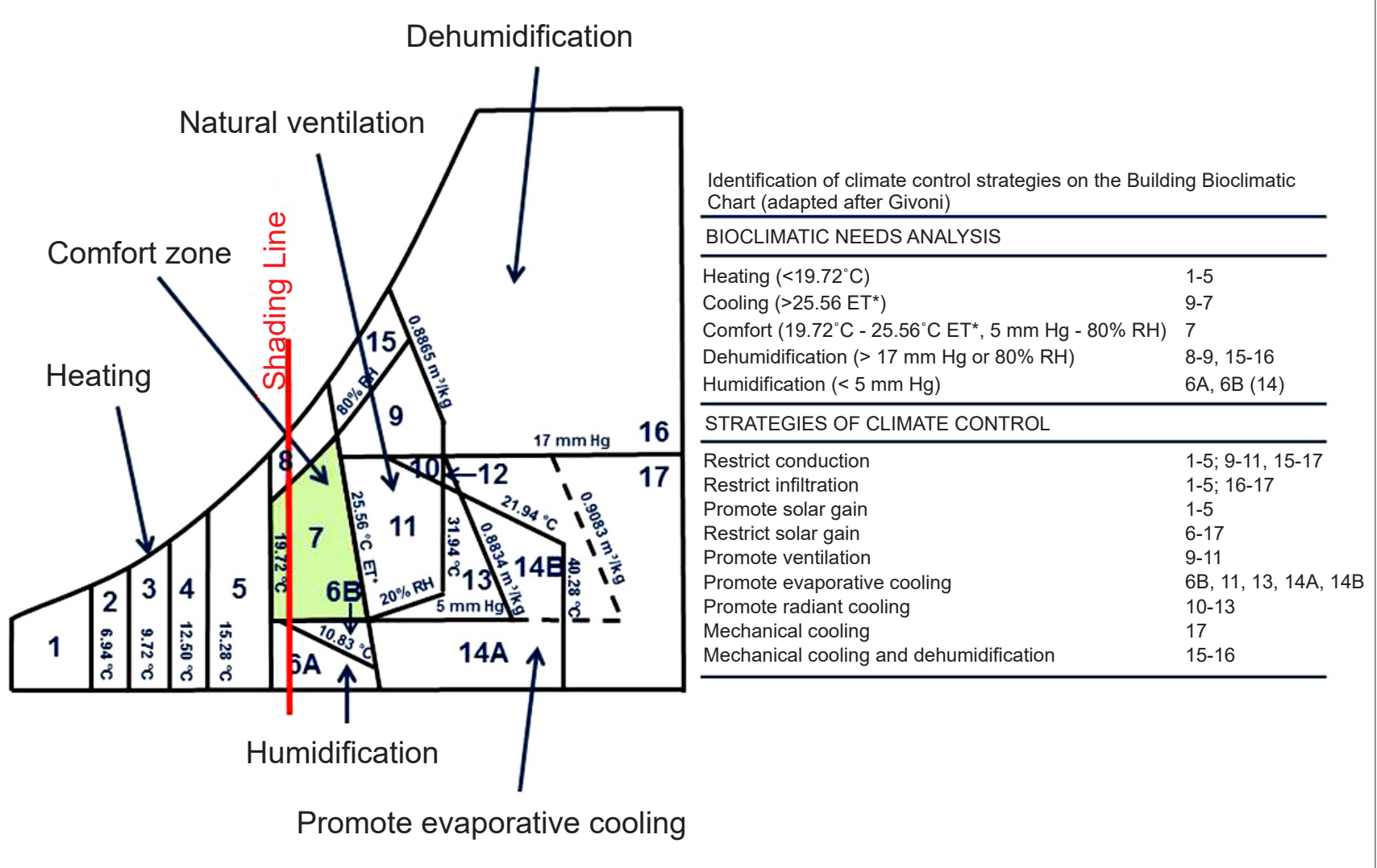

Figuur 4: Klimaatbeheerstrategieë as 'n oorlegging op 'n vereenvoudigde psigrometriese kaart

Bron: $\quad$ Gebasseer op Watson \& Labs, 1983: 206

gee dan 'n baie goeie aanduiding van watter ontwerpstrategieë die toepaslikste gaan wees vir die betrokke klimaat.

Die gedetailleerde tabelle hieronder is deur die outeur bereken met behulp van die gevorderde Climate Consultant v5.4 programmatuur wat deur Robin Liggett en Murray Milne van die UCLA Energy Design Tools Group met tegniese ondersteuning van Carlos Gomez en Don Leeper ontwikkel is. Hierdie programmatuur stel 'n gebruiker in staat om die klimaat van 'n betrokke plek in detail te ontleed met behulp van grafieke, sonskadukaarte, en ander hulpmiddels. Die kragtigste aspek is egter ' $n$ elektroniese weergawe van die psigrometriese kaart wat in Figuur 4 geïllustreer is. Die temperatuur en humiditeit vir elke uur van die jaar (8 760 uur) word as kolletjies as 'n oorlegging geskep op 'n agtergrond soos die wat in Figuur 4 geïllustreer is. Die program gaan dan verder en bereken die hoeveelheid ure (hoeveelheid uur kolletjies) wat binne die betrokke strategiesones val. Met gebruikmaking van die teoretiese werk wat Givoni en Milne (1979: 96-113) gedoen het, kan dan bepaal word watter passiewe ontwerpstrategieë die toepaslikste gaan wees om 'n gerieflike gebou te skep. Die program gaan selfs verder en kan die mees optimale stel maatreëls bereken.Om 'n gedetailleerde klimaatanalise te doen, word 'n klimaatlêer (weather file) vereis. 'n Klimaatlêer bevat die klimaatmetings van onder andere temperatuur, humiditeit, reënval, windspoed, wolkbedekking, en sonstraling vir 'n tipiese jaar vir die betrokke plek. Hierdie klimaatlêers is ongelukkig nog nie vryelik beskikbaar in Suid-Afrika nie. Die outeur het dus die klimaatlêers wat in die analises gebruik is, met behulp van die Meteonorm programmatuur geskep. Meteonorm is 'n gevorderde weerkundige databasis wat ontwikkel is vir ingenieurs, beplanners, en opleidingsdoeleindes. Dit is ontwikkel deur die Meteotest Genossenschaft maatskappy wat in Bern, Switserland geleë is. Bo en behalwe direk gemete weerstasies is die programmatuur ook in staat om geinterpoleerde klimaatlêers te skep vir plekke waar daar geen weerstasie is nie. Laasgenoemde is nie $100 \%$ korrek nie, maar is beter as geen data nie. Temperatuur en humiditeit kan suksesvol geinterpoleer word, maar nie windsterkte en -rigting nie, omdat wind baie beïnvloed word deur topografie. Die korrelasies tussen die klimaatlêers en die relevante KöppenGeiger klimaatstreek is gedoen deur middel van die hoë resolusie WNNR ontwikkelde Köppen-Geiger klimaatkaart (Figuur 1).

Tabelle 6 en 7 illustreer sommige van die gekwantifiseerde ontwerpstrategieë wat gebruik kan word om die aangenaamheid van geboue in die konteks van die verskillende KöppenGeiger klimaatsstreke in Suid-Afrika te verbeter.

Tabelle 6 en 7 wat ter illustrasie vir die BSk en Cwb klimaatstreke (twee van die 13 klimaatstreke in Suid-Afrika) gebruik is, sluit stede soos Bloemfontein, Johannesburg, en Pretoria in. 
Tabel 6: Gekwantifiseerde strategieë vir Koppen-Geiger klassifikasie BSk

\begin{tabular}{|l|c|c|c|c|c|c|c|c|}
\hline \multirow{2}{*}{\multicolumn{1}{|c|}{ Strategie }} & $\begin{array}{c}\text { Aliwal- } \\
\text { Noord }\end{array}$ & Bloemfontein & Calvinia & $\begin{array}{c}\text { Langebaanweg } \\
\text { SAAF }\end{array}$ & $\begin{array}{c}\text { Middelburg } \\
\text { Kaap }\end{array}$ & Mosselbaai & Welkom \\
\cline { 2 - 8 } & \multicolumn{7}{|c|}{ Urearliks } \\
\hline Gerieflik & 1580 & 1623 & 1157 & 1996 & 1458 & 1974 & 1649 \\
\hline Sonbeskerming van vensters & 1815 & 1815 & 1829 & 1774 & 1637 & 1739 & 2246 \\
\hline Hoë termiese massa & 796 & 880 & 747 & 592 & 700 & 359 & 1257 \\
\hline $\begin{array}{l}\text { Hoë termiese massa met nagverkoeling (night } \\
\text { flushed) }\end{array}$ & 805 & 897 & 790 & 597 & 703 & 366 & 1315 \\
\hline Direkte verdampingsverkoeling & 723 & 762 & 1347 & 476 & 577 & 140 & 1470 \\
\hline Twee-stadium verdampingsverkoeling & 815 & 885 & 1363 & 534 & 673 & 224 & 1596 \\
\hline Natuurlike ventilasieverkoeling & 0 & 0 & 0 & 0 & 0 & 0 & 0 \\
\hline Waaier-geforseerde ventilasieverkoeling & 772 & 779 & 443 & 774 & 691 & 991 & 989 \\
\hline Interne hittewins & 2835 & 2768 & 2841 & 3760 & 2947 & 4283 & 2768 \\
\hline Passiewe direkte son hittewins (lae massa) & 1386 & 1374 & 1315 & 1193 & 1553 & 1090 & 787 \\
\hline Passiewe direkte son hittewins (hoë massa) & 2786 & 2686 & 2728 & 2591 & 2838 & 2537 & 2500 \\
\hline Windbeskerming van buiteruimtes & 65 & 65 & 33 & 0 & 71 & 23 & 3 \\
\hline Slegs bevogtiging & 121 & 91 & 675 & 0 & 67 & 0 & 454 \\
\hline Slegs ontvogtiging & 149 & 128 & 25 & 148 & 127 & 470 & 153 \\
\hline Verkoeling (voeg ontvogtiging by indien nodig) & 54 & 48 & 27 & 67 & 71 & 63 & 157 \\
\hline Verhitting (voeg bevogtiging by indien nodig) & 1385 & 1376 & 1359 & 1180 & 1480 & 848 & 951 \\
\hline
\end{tabular}

Bron: Conradie, 2013: 101-117

Tabel 7: Gekwantifiseerde strategieë vir Köppen-Geiger klassifikasie Cwb

\begin{tabular}{|c|c|c|c|c|c|c|c|}
\hline \multirow[t]{2}{*}{ Strategie } & Bethal & Bethlehem & Ermelo & Estcourt & $\begin{array}{l}\text { Johannesburg } \\
\text { (OR Tambo) }\end{array}$ & $\begin{array}{c}\text { Pretoria } \\
\text { (Irene) }\end{array}$ & Standerton \\
\hline & \multicolumn{7}{|c|}{ Ure/jaarliks } \\
\hline Gerieflik & 2129 & 1540 & 1451 & 1866 & 1740 & 1863 & 2172 \\
\hline Sonbeskerming van vensters & 1978 & 1449 & 1387 & 1848 & 1463 & 1776 & 2043 \\
\hline Hoë termiese massa & 684 & 254 & 216 & 758 & 237 & 520 & 851 \\
\hline Hoë termiese massa met nagverkoeling (night flushed) & 684 & 254 & 216 & 758 & 237 & 520 & 851 \\
\hline Direkte verdampingsverkoeling & 824 & 257 & 308 & 677 & 224 & 602 & 881 \\
\hline Twee-stadium verdampingsverkoeling & 843 & 271 & 317 & 750 & 245 & 639 & 959 \\
\hline Natuurlike ventilasieverkoeling & 0 & 0 & 0 & 0 & 0 & 1 & 3 \\
\hline Waaier-geforseerde ventilasieverkoeling & 728 & 401 & 289 & 986 & 475 & 873 & 945 \\
\hline Interne hittewins & 3379 & 3291 & 3569 & 3329 & 3746 & 3740 & 3282 \\
\hline Passiewe direkte son hittewins (lae massa) & 1018 & 1765 & 1676 & 1048 & 1501 & 1153 & 936 \\
\hline Passiewe direkte son hittewins (hoë massa) & 2653 & 2996 & 2805 & 2454 & 2651 & 2508 & 2603 \\
\hline Windbeskerming van buiteruimtes & 0 & 1 & 51 & 35 & 7 & 2 & 0 \\
\hline Slegs bevogtiging & 269 & 129 & 170 & 142 & 67 & 277 & 201 \\
\hline Slegs ontvogtiging & 74 & 92 & 36 & 243 & 140 & 258 & 131 \\
\hline Verkoeling (voeg ontvogtiging by indien nodig) & 5 & 0 & 0 & 10 & 0 & 3 & 8 \\
\hline Verhitting (voeg bevogtiging by indien nodig) & 978 & 1445 & 1501 & 1110 & 1362 & 958 & 948 \\
\hline
\end{tabular}

Bron: Conradie, 2013: 101-117

Die dorre BSk klimaatstreek is op die oomblik die grootste enkele klimaatstreek in Suid-Afrika, met $23.81 \%$ van die oppervlakte.

Sonbeskerming in die somer (sun shading of windows) en hittewins in winter (passive solar direct gain high/low mass) is belangrik omdat dit baie koud word in die winter.

Omdat dit 'n dorre streek is, is verdampingsverkoeling ook effektief in sommige van die gebiede.

Die Cwb klimaatstreek is relatief hoog geleë, bedek $12.1 \%$ van die landsoppervlakte, en is bekend as die "Hoëveld". Hierdie klimaatstreek sluit Johannesburg en gedeeltes van Pretoria in. Ontwerpstrategieë wat oorweeg kan word, is sonbeskerming van venters (sun shading of windows), hittewins in die winter (heat gains in winter) en tot 'n mindere mate waaier-geforseerde 
ventilasie-verkoeling (fan-forced ventilation cooling).

Bo en behalwe die bioklimatologiese benadering het Van Hove et al. (2014: 56) die maatreëls in Tabel 8 gelys. Nie al die betrokke maatreëls is van toepassing in Suid-Afrika nie omdat die betrokke navorsing in Nederland onderneem is, wat 'n groot probleem met te veel water het. Die simbole in Tabel 8 het die volgende betekenis. Die effektiewiteitssimbole varieer vanaf 'n negatiewe effek (-), geringe tot geen effek (+/-) tot 'n baie positiewe effek $(++)$. Bo en behalwe direkte effekte kan daar ook 'n onderskeid getref word met betrekking tot die veelsydigheid van die maatreël. Die maatreël is generies toepaslik (G), wat beteken dat die effek in die algemeen geldig is, ongeag stedelike of geboutipologie en is ook onafhanklik van die spesifieke konteks. Dit is tipologie gekoppel ( $T$ ), wat beteken dat die effek geldig is vir sekere stedelike of argitektoniese tipologieë en onafhanklik is van 'n spesifieke konteks.
Dit is konteks-afhanklik (C), wat beteken dat die effek van die betrokke maatreël so afhanklik is van plaaslike omstandighede dat dit in elke individuele situasie bepaal moet word.

\subsection{Koel dakke en oppervlaktes}

Baie dakke in Suid-Afrika is donker van kleur en bereik hoë temperature op warm sonnige dae. Hierdie dakke stoor, en stel dan 'n aansienlike hoeveelheid energie vry in die atmosfeer. Warm dakke versnel ook die degradering van die betrokke dakmateriale. Geboue met swak isolasie verhoog die hoeveelheid verkoelingsenergie en het 'n negatiewe impak op die gebou se behaaglikheid.

In teenstelling hiermee is dakke wat 'n hoë sonweerkaatsing het of albedo en 'n hoë termiese uitstraling aansienlik koeler as die alternatief. Dit is omdat hierdie dakke baie minder sonenergie berg gedurende die dag en dus nie groot uitstralers van hitte gedurende die nag is nie.

Tabel 8: Oorsig van boukundige maatreëls

\begin{tabular}{|c|c|c|c|}
\hline Maatreël & Doelwit & Effektiwiteit & Tipe \\
\hline Sonbeskerming (skaduwee) & $\mathrm{H}$ & ++ & G \\
\hline Termiese massa & $\mathrm{H}$ & $+/-$ & G \\
\hline Ventilasie & $\mathrm{H}$ & ++ & G \\
\hline Albedo & $\mathrm{H}$ & + & G \\
\hline Gebou-oriëntasie & $\mathrm{H}$ & ++ & G \\
\hline Groendak (uitgebreid; tradisioneel) & $\mathrm{H} / \mathrm{W}$ & $+/-,+/-$ & $\mathrm{T}$ \\
\hline Groendak (intensief; vertraagde dreinering) & $\mathrm{H} / \mathrm{W}$ & $+/-,+/-$ & $\mathrm{T}$ \\
\hline Bloudak $^{2}$ & W & + & $\mathrm{T}$ \\
\hline Reënwatertenk/bergingstenk & W & + & G \\
\hline Waterberging in kelder ${ }^{3}$ & W & ++ & $\mathrm{T}$ \\
\hline Groen fasades & $\mathrm{H} / \mathrm{W}$ & $+/-$ & G \\
\hline Waterberging in geboue, tuine en binneplase & W & ++ & \\
\hline Verwyder nie-poreuse loopvlakke in tuine & W/H & $+/++$ & G \\
\hline Aktiewe verkoeling & $\mathrm{H}$ & ++ & \\
\hline $\begin{array}{l}\text { H: voorkom hittestres } \\
\text { W: voorkom skade as gevolg van vloedskade } \\
\text { G: Generies } \\
\text { T: Tipologie-gekoppel } \\
\text { C: Konteks-afhanklik }\end{array}$ & & & \\
\hline
\end{tabular}

Bron: Van Hove et al., 2014: 56

2 'n Blou dak (Blue roof) is 'n dak wat spesifiek ontwerp is om water te berg tydens reënval. Daar kan tussen aktiewe en passiewe stelsels onderskei word afhangende van die beheerstelsels wat gebruik word om dreinering van water vanaf die dak te beheer.

3 In Nederland is die kelder waarna hier verwys word 'n lae ruimte onder die huis (crawl space) wat vir die berging van water gebruik kan word.

\subsection{Groen dakke}

Soos koel dakke kan groen dakke 'n betekenisvolle impak hê op die temperatuur binne-in die gebou en die onmiddellike omgewing. Groen dakke bestaan uit 'n aantal komponente wat kan varieer na gelang van die spesifieke toepassing. Die basiese komponente van 'n groen dak is (Bothma, 2010: 209-226):

- Mengsel van plantegroei

- Groeimedium

- Waterretensiemateriaal (opsioneel)

- Filtreermembraan

- Dreineringslaag

- Wortel-afwerende laag.

Wanneer groen dakke in Suid-Afrika gebruik word, moet die klimaat in ag geneem word. In die dorre klimaatstreke kan die vinnige verdamping uit die onderste lae veroorsaak dat die waterdigte membraan kraak of gate kry. Dit kan aansienlike probleme veroorsaak as die water die dak binnedring, asook skimmel, effloressensie, en die roes van staalbewapening. Daarenteen in baie nat klimate kan die staande water in die onderlae veroorsaak dat die dak ' $n$ habitat word vir ongewenste insekte soos muskiete. Die korrekte keuse van plante, die ontwerp van die onderlae, en die waternetwerk is belangrik onder hierdie toestande (Bothma, 2010: 209-226).

\subsection{Sinvolle gebruik van glas in Suid-Afrika}

In 2014 was die Suid-Afrikaanse markgrootte vir konstruksieglas 7.3 miljoen $\mathrm{m}^{2}$ glas. Die grootste gedeelte hiervan is konvensionele glas (83\%) en die res is gelamineerde en getemperde glas (Van Wyk, Ampofo-Anti \& Dumani, 2015: 47).

In terme van klimaatverandering is dit belangrik om die eienskappe van glas te verstaan wanneer ontwerpers, argitekte, en bouers glas kies. Op die oomblik word die gebruik van glas in Suid-Afrika nog nie as 'n belangrike energie-effektiewe maatreël beskou nie. Gewone vensters is berug vir ongewenste hittewins en -verlies en in baie gevalle sal dit nie aan die betrokke boukundige regulasies soos 
die SANS 10400-XA voldoen nie. Die aantal vensters en die plasing rondom die gebou, sonbeskerming, en optimale oriëntasie is uiters belangrik.

Die grootskaalse gebruik van glas in moderne geboue het 'n groot impak op die energie-effektiwiteit van 'n gebou. Insgelyks het dit ook 'n direkte impak op die SHE-effek en die opbou van hitte in die stedelike klowe tussen geboue. Die grootskaalse gebruik van glas in geboue is begin met pioniersprojekte soos Crystal Palace wat oorspronklik in Hyde Park in Londen opgerig is. Dit was 'n gietyster en spieëlglas-gebou wat opgerig is om die groot uitstalling van 1851 te huisves.

Glas kan as die swakste skakel in die fasade van 'n gebou beskou word in vergelyking met die res van die konstruksiemateriale, selfs al word dubbelbeglasing of spesialis tipes glas soos lae-E gebruik. Ter illustrasie het die outeur ses tipiese beglasings vergelyk wat in Suid-Afrika gebruik word (Tabel 9). Bo en behalwe die U-waardes toon Tabel 9 ook die Son Hittewinskoëffisiënt aan (Solar Heat Gain Coefficient [SHGC]). Let op die relatiewe swak U-waardes van selfs sogenaamde hoë werkverrigting beglasing. In die boubedryf is dit noodsaaklik om oor 'n maatstaf te beskik waardeur die termiese gedrag van konstruksie-elemente, hetsy 'n betonmuur of 'n liggewig invulpaneel, met mekaar te vergelyk. So 'n maatstaf is die U-waarde wat die hoeveelheid hittevoortplanting van lug aan die een kant van 'n element tot lug aan die ander kant aandui. Die
U-Solve programmatuur is gebruik om die berekenings te doen. Dit is ook duidelik hoe min die U-waarde verbeter met 'n vermeerdering in die dikte van die glas. Simulasies drie en vyf is identies behalwe dat vyf 'n lae-E tipe glas gebruik. Op soortgelyke wyse is simulasies vier en ses identies behalwe dat ses lae-E glas gebruik (Conradie \& Szewczuk, 2015: 114-121).

\subsection{Bome as 'n maatreël om SHE te verminder}

Bome is 'n baie nuttige maatreël om stedelike verwarming te verminder. Bome verskaf nie alleen skaduwee en verminder sodoende die SHE effek nie, maar is terselfdertyd 'n baie effektiewe koolstofput. 'n Koolstofput is die proses of meganisme wat koolstofdioksied (kweekhuisgas) uit die atmosfeer verwyder. Koolstof word gesekwestreer en in die bome se hout teen verskillende tempos en hoeveelhede geberg afhangende van faktore soos groeitempo, boomspesie, grootte by volwassenheid, en lewensduur (Stoffberg, Van Rooyen, Van der Linde \& Groeveld, 2010: 9). Talle internasionale studies bevestig genoemde voordele. Kuittinen, Moinel \& Adalgeirsdottir (2016: 623-632) het die stedelike ekosisteme in die Finse stad Espoo bestudeer. Hulle het na sewe verskillende behuisingskomplekse gekyk en bevind dat opname van $\mathrm{CO}_{2}$ deur die koolstofput van groeiende plante en opname van grond organiese koolstof baie varieer. Die sekwestrasie as 'n persentasie van alle vrystellings het gevarieer van $1.2 \%$ tot 'n meer betekenisvolle waarde van $11.9 \%$. Die beste waarde was gemeet by 'n alleenstaande huis op 'n groot terrein en die laagste waarde vir 'n woonstelbok.

Stoffberg et al. (2010: 9-14) het geskatte koolstofsekwestrasie waardes vir straatbome in Pretoria (Tshwane) uitgevoer. Die Stad Tshwane Metropolitaanse Munisipaliteit het ' $n$ strategie in 2002 geformuleer om 115200 inheemse straatbome gedurende die tydperk van 2002-2008 aan te plant. Die resultate van groei regressie verwantskappe was gebruik om die koolstofsekwestrasie tempo van die verskillende spesies onder beskouing te bereken. Dit was gebruik om die totale koolstofsekwestrasie vir 'n 30 jaar periode (2002-2032) te bereken. Dit is geskat dat die boomplanting sou lei tot 'n geskatte 200492 ton ekwivalente $\mathrm{CO}_{2}$ vermindering en dat 54630 ton koolstof sou gesekwestreer word. Die bome het ook 'n groot potensieële monetêre waarde. Die navorsing is op drie inheemse spesies gebaseer, naamlik Combretum erythrophyllum (Vaderlandswilg), Searsia lancea (Karee) en Searsia pendulina (Witkaree). Hierdie basisinligting was gebruik om die koolstofsekwestrasie van die ander boomspesies soos Acacia caffra en Galpinia transvaalica in die studie te bepaal.

\section{GEVOLGTREKKINGS}

Die huidige klimaat van Suid-Afrika is alreeds oorwegend dor met $70.9 \%$ van die landoppervlakte wat in die Köppen-Geiger kategorieë BSh, BSk,

Tabel 9: Tipiese vensterkonfigurasies ontleed met behulp van die $U$-Solve programmatuur

\begin{tabular}{|c|c|c|c|c|c|}
\hline No & Type of glass & Frame & U-value whole window $\left(\mathrm{W} / \mathrm{m}^{2} \mathrm{~K}\right)$ & $\begin{array}{l}\text { U-value centre of glass } \\
\qquad\left(\mathrm{W} / \mathrm{m}^{2} \mathrm{~K}\right)\end{array}$ & SHGC \\
\hline 1 & PFG Clearvue $4 \mathrm{~mm}$ & Casement 38 & 6.14 & 5.879 & 0.661 \\
\hline 2 & PFG Intruderprufe 6.38 mm & Casement 38 & 6.01 & 5.749 & 0.637 \\
\hline 3 & $\begin{array}{l}\text { PFG } 20 \mathrm{~mm} \text { Clearvue Insulated Glass Unit ( } 4 \mathrm{~mm} \\
+12 \mathrm{~mm} \text { air gap }+4 \mathrm{~mm} \text { ) }\end{array}$ & Casement 38 & 3.77 & 2.729 & 0.580 \\
\hline 5 & $\begin{array}{l}\text { PFG } 20 \text { mm Clearvue Insulated Glass Unit Low-e } \\
94 \mathrm{~mm}+12 \mathrm{~mm} \text { air gap }+4 \mathrm{~mm} \text { ) }\end{array}$ & Casement 38 & 3.05 & 0.679 & 0.526 \\
\hline 6 & $\begin{array}{l}\text { PFG } 25 \mathrm{~mm} \text { Intruderprufe Insulated Glass Unit } \\
(6.38 \mathrm{~mm}=12 \mathrm{~mm}+6.38 \mathrm{~mm} \text { low-e) }\end{array}$ & Casement 38 & 2.99 & 1.878 & 0.486 \\
\hline
\end{tabular}

Bron: 
BWh en BWk val (Conradie, 2012: 181-195). Uit die voorafgaande is dit duidelik dat Suid-Afrika aansienlike klimaatverandering te wagte kan wees wat 'n groot impak op stede gaan hê, met 'n geweldige uitbreiding van genoemde dorre klimaatstreke. Op die oomblik word die A2 klimaatverandering scenario deur Suid-Afrikaanse navorsers aanvaar as die waarskynlikste klimaatverandering scenario.

Daar is gelukkig 'n wye verskeidenheid maatreëls wat getref kan word op gebou-, buurt- en stadsvlak om die SHE-effek te verminder soos die gebruik van koel oppervlaktes, groen dakke en die gebruik van bome en plantegroei. Die artikel bespreek die potensiële koolstofsekwestrasie van stadsbome. Die lae bevolkingsdigtheid van baie Suid-Afrikaanse stede is kommerwekkend omdat dit aanleiding gee tot ' $n$ verhoogde SHE en dit vervoerkoste uitermate verhoog as gevolg van reisafstande en die verhoogde koolstofspoor. Nuwe stede behoort baie meer kompak beplan te word.

Bioklimatologiese analises toon aan dat daar baie gedoen kan word met passiewe ontwerpbeginsels vanuit 'n gebou-ontwerp oogpunt om nie alleen die geboue gerieflik te maak nie, maar ook om energie te bespaar. In 'n warm land soos Suid-Afrika is die korrekte gebou-oriëntasie en behoorlike sonbeheer een van die belangrikste aspekte. Sonbeheer gaan hand-aan-hand met die gebruik van 'n sinvolle hoeveelheid glas in gebou-fasades.

\section{VERWYSINGSLYS}

AGROMETEOROLOGY STAFF. 2001. ARC-ISCW Climate Information System. ARC-Institute for Soil, Climate and Water, Pretoria.

BOTHMA, J. 2010. Greening the building: Plants, planting and detailing. In: Van Wyk, L. (Ed.). The green building handbook South Africa. The essential guide, Vol. 3, Alive2Green, pp. 209-226.

CLAY, R., GUAN, H., WILD, N., BENNETT, J., VINODKUMAR, S.H. \& EWENZ, C. 2016. Urban heat island traverses in the City of Adelaide,
South Australia. Urban Climate, 17, pp. 89-101. https://doi.org/10.1016/j. uclim.2016.06.001

CONRADIE, D.C.U. 2012. Designing for South African climate and weather. In: Van Wyk, L. (Ed.). The green building handbook South Afric., The essential guide, Vol. 4. Alive2Green, pp. 181-195.

CONRADIE, D.C.U. 2013. Appropriate passive design approaches for the various climatic regions in South Africa. In: Van Wyk, L. (Ed.). The green building handbook South Africa. The essential guide, Vol. 5. Alive2Green, pp. 101-117.

CONRADIE, D.C.U. \& SZEWCZUK, S. 2015. The use of glass in buildings. In: Van Wyk, L. (Ed.). The green building handbook South Africa. The essential guide, Vol. 8. Alive2Green, pp.113-121.

CONRADIE, D.C.U., VAN REENEN, T. \& BOLE, S. 2015. The creation of cooling degree (CDD) and heating degree day (HDD) climatic maps for South Africa. In: Proceedings of Smart and Sustainable Built Environments Conference 2015 (SASBE 2015), University of Pretoria, 9-11 December 2015, pp. 83-91.

HOWARD, L. 1833. The climate of London. London: Harvey and Darton. (International Association for Urban Climate Edition).

INTERGOVERNMENTAL PANEL ON CLIMATE CHANGE (IPCC). 2000. Emission scenarios, summary for policymakers: A special report of IPCC working group III. Published for the Intergovernmental Panel on Climate Change, pp. 3-5.

EMANUEL, K. 2005. Increasing destructiveness of tropical cyclones over the past 30 years. Nature, 436, pp. 686-688. https://doi.org/10.1038/ nature03906

\section{ENGELBRECHT, C.J. \&}

ENGELBRECHT, F.A. 2016. Shifts in Köppen-Geiger climate zones over Southern Africa in relation to key global temperature goals. Theoretical and Applied Climatology, 123(1), pp. 247-261. https://doi.org/10.1007/ s00704-014-1354-1

ENGELBRECHT, F., ADEGOKE, J., BOPAPE, M-J., NAIDOO, M., GARLAND, R., THATCHER, M., McGREGOR, J., KATZFEY, J., WERNER, M., ICHOKU, C. \& GATEBE, C. 2015. Projections of rapidly rising surface temperatures over Africa under low mitigation.
Environmental Research Letters, 10(2015)085004. doi:10.1088/17489326/10/8/085004, pp. 1-14. https://doi. org/10.1088/1748-9326/10/8/085004

ENGELBRECHT, F.A., LANDMAN, W.A., ENGELBRECHT, C.J., LANDMAN, S., BOPAPE, M.M., ROUX, B., McGREGOR, J.L. \& THATCHER, M. 2011. Multi-scale climate modelling over Southern Africa using a variableresolution global model. Water $S A$, 37(5), WRC 40-Year Celebration Special Edition, p. 649.

GARLAND, R.M., MATOOANE, M., ENGELBRECHT, F.A., BOPAPE, M-J.M., LANDMAN, W.A., NAIDOO, M., VAN DER MERWE, J. \& WRIGHT, C.Y. 2015. Regional projections of extreme apparent temperature days in Africa and the related potential risk to human health. International Journal of Environmental Research and Public Health, 2015(12), doi:10.3390/ ijerph121012577, pp. 12577-12604. https://doi.org/10.3390/ijerph121012577

GIVONI, B. \& MILNE, M. 1979.

Architectural design based on climate. In: Watson, D. (Ed.). Energy conservation through building design. New York: McGraw-Hill, Inc., pp. 96-113.

GOLANY, G. 1978. Urban planning for arid zones: American experiences and directions. New York: John Wiley \& Sons.

HAARHOFF, J. \& VAN DER MERWE, B. 1996. Twenty-five years of wastewater reclamation in Windhoek, Namibia. Water Science and Technology, 33(10-11), pp. 25-35. https://doi. org/10.1016/0273-1223(96)00403-9

HENDEL, M., GUTIERREZ, P., COLOMBERT, M., DIAB, Y. \& ROYON, L. 2016. Measuring the effects of urban heat island mitigation techniques in the field: Application to the case of pavement watering in Paris. Urban Climate, 16, pp. 43-58. https://doi. org/10.1016/j.uclim.2016.02.003

KUITTINEN, M., MOINEL, C. \& ADALGEIRSDOTTIR, K. 2016. Carbon sequestration through urban services: A case study from Finland. Science of the Total Environment, 563-564, pp. 623-632. https://doi.org/10.1016/j. scitotenv.2016.03.168

KOTTEK, M., GRIESER, J., BECK, C., RUDOLF, B. \& RUBEL, F. 2006. World map of the Köppen-Geiger climate classification updated. Meteorologische Zeitschrift, 15(3), pp. 259-263. https:// doi.org/10.1127/0941-2948/2006/0130 
LI, X., LI, W., MIDDEL, A., HARLAN, S.L., BRAZEL, A.J. \& TURNER, B.L. 2016. Remote sensing of the surface urban heat island and land architecture in Phoenix, Arizona: Combined effects of land composition and configuration and cadastral-demographic-economic factors. Remote Sensing of

Environment, 174, pp. 233-243. https:// doi.org/10.1016/j.rse.2015.12.022

MATHEWS, E.H., GEYSER, M.F. \& TAYLOR, P.B. 2000. Defining new condensation boundaries in the Southern Cape. TEMM International (Pty) Ltd for Agrément South Africa, pp. 51.

MAYOR OF LONDON. 2006. London's urban heat island: A summary for decision makers. London: Greater London Authority, p. 2.

McCARTHY, M.P., BEST, M.J. \& BETTS, R.A. 2010. Climate change in cities due to global warming and urban effects. Geophysical Research letters, 37, L09705, doi10.1029/210GL042845, pp. 1-5.

MORGAN, M.H. 1960. Vitruvius, the ten books on architecture. New York: Dover Publications.

NICE, J., KUMIRAI, T., CONRADIE, D.C.U. \& GROBLER, J-H. 2015. A comparison of predicted design efficacy and environmental assessment for tuberculosis care facilities in South Africa. In: Proceedings of Smart and Sustainable Built Environments Conference 2015 (SASBE 2015), University of Pretoria, 9-11

December 2015, pp. 175-184.

OLGYAY, V. 2015. Design with climate: Bioclimatic approach to architectural regionalism. New and Expanded Edition. Princeton, N.J.: Princeton University Press. https://doi. org/10.1515/9781400873685

RUBEL, F. \& KOTTEK, M. 2010. Observed and projected climate shifts 1901-2100 depicted by world maps of the Köppen-Geiger climate classification. Meteorologische Zeitschrift, 19(2), pp. 135-141. https:// doi.org/10.1127/0941-2948/2010/0430

STOFFBERG, G.H., VAN ROOYEN, M.W., VAN DER LINDE, M.J. \& GROEVELD, H.T. 2010. Carbon sequestration of indigenous street trees in the City of Tshwane, South Africa. Urban Forestry \& Urban Greening, 9, pp. 9-14. https://doi.org/10.1016/j. ufug.2009.09.004
THE INTERNATIONAL BANK FOR RECONSTRUCTION AND DEVELOPMENT \& WORLD BANK. 2010. Cities and climate change: An urgent agenda. Washington DC: The International Bank for Reconstruction and Development/The World Bank, pp. 1-81.

VAN HOVE, B., BLOCKEN, B., VAN DEN DOBBELSTEEN, A., SPIT, T. \& BOSCH, P. 2014. Climate-proof cities - Final report. Dutch research programme 'Knowledge for Climate', co-financed by the Dutch Ministry of Infrastructure and Environment.

VAN WYK, L., AMPOFO-ANTI, N.L. \& DUMANI, N. 2015. Potential for reducing greenhouse gas emissions in the South African construction sector. DBSA Green Fund Research and Policy Development to advance a Green Economy in South Africa: Research Report, p. 47.

VISITSAK, S. \& HABERL, J.S. 2004. An analysis of design strategies for climate-controlled residences in selected climates. In: Proceedings of First National IBPSA-USA Conference, Boulder, Colorado, 4-6 August, pp. 1-11.

WARD, K., LAUF, S., KLEINSCHMIT, B. \& ENDLICHER, W. 2016. Heat waves and urban heat islands in Europe: A review of relevant drivers. Science of the Total Environment, 569-570, pp. 527-539. https://doi. org/10.1016/j.scitotenv.2016.06.119

WATSON, D. \& LABS, K. 1983. Climatic design: Energy-efficient building principles and practice. Part II. New York: McGraw-Hill, Inc.

XIAN-XIANG, L. \& NORFORD, L.K. 2016. Evaluation of cool roof and vegetations in mitigating urban heat island in a tropical city, Singapore. Urban Climate, 16 London, pp. 59-74. 